\title{
Blatant Benevolence and Conspicuous Consumption: When Romantic Motives Elicit Strategic Costly Signals
}

\author{
Vladas Griskevicius \\ Arizona State University \\ Jill M. Sundie \\ University of Houston \\ Geoffrey F. Miller \\ University of New Mexico
}

\author{
Joshua M. Tybur \\ University of New Mexico \\ Robert B. Cialdini \\ Arizona State University \\ Douglas T. Kenrick \\ Arizona State University
}

\begin{abstract}
Conspicuous displays of consumption and benevolence might serve as "costly signals" of desirable mate qualities. If so, they should vary strategically with manipulations of mating-related motives. The authors examined this possibility in 4 experiments. Inducing mating goals in men increased their willingness to spend on conspicuous luxuries but not on basic necessities. In women, mating goals boosted public-but not private-helping. Although mating motivation did not generally inspire helping in men, it did induce more helpfulness in contexts in which they could display heroism or dominance. Conversely, although mating motivation did not lead women to conspicuously consume, it did lead women to spend more publicly on helpful causes. Overall, romantic motives seem to produce highly strategic and sex-specific self-presentations best understood within a costly signaling framework.
\end{abstract}

Key words: costly signaling, altruism, conspicuous consumption, mating goals, self-presentation

We should often blush at our noblest deeds if the world were to see all their underlying motives.-Francois de La Rochefoucauld

On Valentine's Day 2003, America's leading authority on philanthropy announced that real estate mogul Donald Trump had pledged \$1 million to charity (Foundation Center, 2003). A few years earlier, media tycoon Ted Turner had pledged an entire billion dollars to humanitarian causes (Cable News Network (CNN) Interactive, 1997). Although such valiant spectacles of public philanthropy are actually fairly common (Plotz, 2006), they seem somewhat puzzling. Trump and Turner, for example, epitomize many people's stereotypes of self-interested and self-serving capitalists; both men appear to obtain great satisfaction from lavish lifestyles and openly flaunt their extravagant private jets, luxurious

Vladas Griskevicius and Douglas T. Kenrick, Department of Psychology, Arizona State University; Joshua M. Tybur and Geoffrey F. Miller, Department of Psychology, University of New Mexico; Jill M. Sundie, Department of Marketing and Entrepreneurship, University of Houston; Robert B. Cialdini, Departments of Psychology and Marketing, Arizona State University.

This research was facilitated by a National Science Foundation Graduate Research Fellowship awarded to Vladas Griskevicius and by National Institutes of Health Grant 5R01MH64734 awarded to Douglas T. Kenrick. We thank Chad Mortensen and Elaine Perea for their helpful comments on a previous version of this article.

Correspondence concerning this article should be addressed to Vladas Griskevicius, Department of Psychology, Arizona State University, Tempe, AZ 85287-1104. E-mail: vladasg@asu.edu yachts, and chauffeured limousines. Yet each of these seemingly selfish tycoons chose to give away a phenomenal amount of their own money to complete strangers. What motives might underlie such costly and apparently selfless deeds?

The current research investigated the idea that self-sacrifice might actually be self-presentation. Although it may have been mere coincidence that Trump's donation was announced on Valentine's Day, there may indeed be a connection among philanthropic displays, lavish spending, and courtship. In particular, we examined whether public philanthropy-and conspicuous displays of consumption and benevolence-can be elicited by romantic motives. In our framework, such displays are considered through the lens of costly signaling theory, which is a biological model that has inspired a number of studies of animal behavior but has thus far received little attention in psychology. The central tenet of costly signaling theory is that a variety of conspicuous animal displays, such as the peacock's tail, can serve important communicative functions, advertising an individual's ability to garner scarce resources and possibly signaling the possession of desirable traits that could be passed on to offspring (Grafen, 1990; Miller, 2000; Zahavi, 1975). More generally, our research builds on previous work on mate preferences not only by examining specific tactics that are triggered by romantic contexts but also by considering how behaviors that at first glance do not appear to be linked to mating may be indirectly linked to broader mating strategies (Daly \& Wilson, 1988; Griskevicius, Goldstein, Mortensen, Cialdini, \& Kenrick, 2006; Simpson, Gangestad, Christensen, \& Leck, 1999). 


\section{Evolution of Prosocial Behavior}

Donating one's own resources to a charitable cause seems to be the essence of altruism - an action that provides a benefit to others while incurring a cost to the self (Barrett, Dunbar, \& Lycett, 2002). Research on prosocial behavior has a rich history in psychology and has focused mainly on identifying situational factors that promote helpful behavior (Batson, 1998; Penner, Dovidio, Piliavin, \& Schroeder, 2005). Impressively, decades of work have uncovered many such help-promoting factors, including social norms, rewards, empathy, mood, and number of bystanders (Berkowitz, 1972; Cialdini et al., 1987; Latane \& Darley, 1970; Schaller \& Cialdini, 1990). However, psychological models of helping have only more recently begun to address the questions of why and how factors such as empathy became so relevant in eliciting prosocial behavior (MacAndrew, 2002; Van Vugt \& Van Lange, 2006).

From an evolutionary perspective, the manner in which prosocial behavior evolved has always been somewhat puzzling. On the surface, natural selection would not appear to favor individuals who give away their own resources to benefit others. However, such helping is comprehensible in light of inclusive fitness or kin selection theory (Hamilton, 1964), which posits that individuals' actions are designed not so much to ensure the survival of the individual but to ensure the survival of the genes making up that individual—genes that are shared with one's kin (Dawkins, 1989). Consistent with kin selection theory, individuals across cultures and animals across species behave more benevolently toward others the more closely the givers are related to the recipients of the aid (Burnstein, Crandall, \& Kitayama, 1994; Essock-Vitale \& McGuire, 1985; Neyer \& Lang, 2003; Sherman, 1981).

Kin selection theory, however, does not explain benevolence toward nonrelatives. Evolutionary theorists have explained such nonkin helping in light of the theory of reciprocal altruism (Trivers, 1971), whereby individuals are believed to help nonrelatives because the helpers benefit by being helped in return. This theory has not only been fruitful in explaining helping and cooperative behaviors across societies and species (Axelrod \& Hamilton, 1981; Fehr, Gachter, \& Kirchsteiger, 1997; Hawkes, 1992; Stanne, Johnson, \& Johnson, 1999; Wilkinson, 1984), but it is also congruent with psychological mechanisms related to detecting nonreciprocating cheaters (Cosmides \& Tooby, 1992).

Yet neither kin selection nor reciprocal altruism can fully explain large philanthropic gifts to nonkin or even handouts to beggars who will never reciprocate these favors (Dugatkin, 1997; MacAndrew, 2002). For instance, it is difficult to understand from either perspective why $70 \%$ of U.S. households give money to charity (American Association of Fundraising Counsel, 2005) or why nearly 10 million Americans each year give blood to strangers whom they'll never meet (Piliavin \& Callero, 1991).

\section{Costly Signals and Handsome Rewards}

A theory that may help explain such benevolent and often expensive behaviors is costly signaling theory (Grafen, 1990; Zahavi, 1975). Costly signaling theory, which is related to the handicap principle (Zahavi \& Zahavi, 1997), suggests that individuals often engage in behaviors that are costly (i.e., involve significant amounts of economic resources, energy, risk, or time) as a way of signaling to others useful information about themselves (Bird \& Smith, 2005; MacAndrew, 2002). This theory was developed in the field of behavioral ecology and has garnered much empirical support in studies of both animal signaling and anthropology (Gurven, Allen-Arave, Hill, \& Hurtado, 2000; Lotem, Fishman, \& Stone, 2002; Smith \& Bird, 2000; Sosis, 2000). However, costly signaling theory is only beginning to influence thinking in psychology (Miller, 2000). The classic example of a costly signal is the peacock's tail, whereby the quality of the tail—its size, color, luminosity, and symmetry—serves as an honest signal of the quality of the peacock's genes to potential mates. A high-quality tail is costly to have because it takes much metabolic energy and resources to grow and maintain such a resplendent ornament, which is useless and even detrimental in other aspects of a peacock's life; a high-quality tail is an honest signal of good genes because only those peacocks who are in good health and who have the traits required to survive and acquire abundant supplies of food can afford to waste their energy and resources to grow and maintain this showy and nutritionally costly ornament (Loyau, Saint Jalme, Cagniant, \& Sorci, 2005; Møller \& Petrie, 2002).

According to a costly signaling perspective, public philanthropy might be a conspicuous display of resources and generosity that signals an individual's ability to incur costs by sacrificing-or even wasting - money and time (without reaping the benefits of aiding kin or future reciprocation). Such philanthropic displays serve to increase the signaler's status and prestige (Boone, 1998; Hardy \& Van Vugt, 2006; Roberts, 1998), which may ultimately increase the signaler's ability to attract and retain desirable mates (Goldberg, 1995; Miller, 2000; Mulcahy (1999) as cited in Barrett et al., 2002). Costly signaling theory has several similarities with classic social theories dating back to Thorstein Veblen (1899/ 1994) and Marcel Mauss (1924). Although these classic sociological theories did not connect conspicuous behaviors directly to mating, they did view public displays of luxuries and magnanimity as a form of social competition, in which the most generous, self-sacrificial, or wasteful individuals gain the most prestige (see Bird \& Smith, 2005). For example, in the Northwest American Kwakiutl tribal practice of potlatching, local chiefs compete to give away-or sometimes even publicly burn-enormous quantities of their own possessions, often going into great debt to do so (Cole \& Chaikin, 1990; Rosman \& Rubel, 1971; Suttles, 1991). The chief who is able to give away or waste the most resources, and thus is able to bear the highest costs, is regarded as the highest status member in the group (Murdock, 1970).

For a behavior to qualify as a costly signal, it must meet four criteria (Smith \& Bird, 2000). First, it must be costly to the signaler in terms of economic resources, time, energy, risk, or some other significant domain, whereby the costlier the behavior the more likely it is to be an honest indicator. Second, it must be easily observable by others. Third, the display must ultimately increase the odds that the signaler will gain some fitness advantage through the display, such as increased ability to attract desirable mates. Finally, the signal must be an indicator to potential mates of some important trait or characteristic, such as access to resources, prosocial orientation, courage, health, or intelligence (Zahavi \& Zahavi, 1997). Public acts of philanthropy clearly meet the first three criteria: They are costly, observable, and produce an increase in prestige. However, conspicuous generosity can signal multiple 
traits in the philanthropist - and the displays of some such traits may be more important depending on whether the signaler is a man or a woman.

\section{Sending Mixed Messages}

A public act of philanthropy can signal at least two clusters of important characteristics about a person: First, it can signal that an individual has resources or, at least, that a person is capable of procuring resources (Boone, 1998; Miller, 2000); second, it can signal that an individual has a prosocial personality, whereby the willingness to use one's resources to help others instead of helping only oneself suggests that a person is kind, sympathetic, and helpful (Miller, 2007). Although both resource-related and prosocial traits are generally desirable in a romantic partner (Buss, 2003), their relative desirability in a mate may differ for men and women (Kenrick, Sadalla, Groth, \& Trost, 1990; Li, Bailey, Kenrick, \& Linsenmeier, 2002; Saad \& Gill, 2003). If so, men and women may be differentially likely to display one or perhaps both traits when motivated to attract a mate.

\section{Resources and Conspicuous Consumption}

Although public philanthropy can convey that one has many resources, perhaps a more common way to display one's wealth is by purchasing lavish and unnecessary things-a concept dubbed conspicuous consumption (Veblen, 1899/1994). Conspicuous consumption is the act of spending money to gain status and impress others by indicating that one has enough money to purchase frivolous and wasteful goods. For instance, although Americans donated around $\$ 2$ billion to help the victims of Hurricane Katrina, Americans spend almost $\$ 2$ billion each year to purchase and fuel their Hummers - a highly conspicuous and wasteful sports utility vehicle (SUV) that consumes a gallon of fuel every 8-11 miles. In fact, Americans spend over $\$ 130$ billion on SUVs each year (many of which are used by the owners only to commute alone to white-collar office jobs) and spend much more than that on extravagant mansions, dinners, yachts, jewelry, and other conspicuous purchases (see Frank, 1999; Silverstein \& Fiske, 2003; Twitchel, 2003). From a purely rational perspective, spending money on unnecessary and wasteful purchases as opposed to making more efficient investments might seem counterintuitive. From a costly signaling perspective, however, conspicuous consumption in humans may serve a conceptually analogous function to a peacock's conspicuous display of his tail (Miller \& Todd, 1998; Saad, 2007).

Although much research already indicates that the ability to procure resources is a highly valued trait in a potential mate (e.g., Buss \& Schmitt, 1993), little work has examined whether mating contexts would indeed lead to displays of conspicuous consumption, which should generally enhance the likelihood of attracting a mate. Research on human mate choice, however, suggests that the conspicuous display of resources ought to be used more frequently by men than women because women place considerably more emphasis on cues of wealth and status when selecting a romantic partner (Buss, 1989; Kenrick, Sundie, Nicastle, \& Stone, 2001; Townsend \& Levy, 1990). For example, women indicate that economic resources in a man are a necessity, whereas men appraise economic resources in a woman as a luxury (Li et al., 2002;
Li \& Kenrick, 2006). Consistent with this asymmetry in preferences, mere exposure to an attractive opposite-sex individual induces men, but not women, to place a higher value on having wealth and being ambitious (Roney, 2003; Wilson \& Daly, 2004). Thus, a romantic motive should lead men, but not necessarily women, to increase their displays of conspicuous consumption.

\section{Prosocial Orientation and Blatant Benevolence}

In addition to signaling wealth, public philanthropy can also convey prosocial personality traits (Penner \& Finkelstein, 1998; Van Lange, Otten, DeBruin, \& Joireman, 1997). Whereas conspicuous consumption may reveal a person's selfishness and narcissism, public philanthropy may reveal virtuous characteristics, such as kindness, sympathy, and helpfulness (Miller, 2007). However, one does not need to give away wads of cash to be seen as helpful. Even a poor person could do public volunteer work in the community, donate blood, or solicit donations for noble causes in a crowded mall-all of which are types of publicly visible prosocial behavior called blatant benevolence (Alexander, 1979; Penner et al., 2005; Roberts, 1998). Blatant benevolence is a prosocial behavior that is costly in terms of time and effort, that is useful for publicizing one's prosocial nature, and that is not necessarily efficient at providing aid to those in need. For example, a wealthy venture capitalist can donate several hours of his or her time to publicly volunteer for a good cause, even though that person can use the same time to earn and donate money that would provide significantly more aid to those who need it.

Although previous work has established that prosocial traits are generally desirable in a potential mate (Brase, 2006; Graziano, Jensen-Campbell, Todd, \& Finch, 1997), little work has examined whether mating contexts lead to an increase in the display of helpfulness, which is likely to increase the probability of attracting a mate. It is also unclear whether there are sex differences in the tendency to display prosocial traits in a mating context. For instance, although it is reasonably clear that men value prosocial traits in romantic partners, the degree to which a man improves his desirability as a mate by displaying helpfulness is less obvious.

On the one hand, women seem to value prosocial traits in a man (Botwin, Buss, \& Shackelford, 1997; Brase, 2006; La Cerra, 1995), possibly because such characteristics reveal a man's willingness to invest in offspring (Ellis, 1992; Feingold, 1992; Miller \& Todd, 1998). On the other hand, women seem to prefer a combination of prosocial and dominance-related traits over either trait alone (Green \& Kenrick, 1994; Jensen-Campbell, Graziano, \& West, 1995, Study 2; Kelly \& Dunbar, 2001). Moreover, women sometimes prefer male sexual partners who are openly competitive rather than warm and agreeable (Gangestad, Simpson, Cousins, Garver-Apgar, \& Christensen, 2004). Such findings are also consistent with research showing that although romantic motives lead women to generally become more group-oriented, they lead men to become less group-oriented (Griskevicius, Goldstein, Mortensen, Cialdini, et al., 2006). Overall, this reasoning suggests two competing hypotheses: A mating motive could either lead both women and men to blatantly display benevolence given that helpfulness is a desirable trait to either sex, or it might lead to a boost in blatant benevolence only for women. 


\section{Study 1}

An evolutionary perspective generally holds that mental mechanisms should be highly sensitive to ecological cues indicating particular adaptive problems or opportunities, such as mating opportunities (Bugental, 2000; Kenrick, Li, \& Butner, 2003; Schaller, Park, \& Mueller, 2003). Much research has also shown that various cues can activate specific goal states that can influence behavior (e.g., Chartrand \& Bargh, 2002; Schaller, 2003). In line with this work, cues related to mating can activate a mating goal and its associated affective responses (Fisher, 2002; Plutchik, 1980), which in turn promote a cascade of functional perceptions, cognitions, and behaviors associated with mating success (Griskevicius, Goldstein, Mortensen, Cialdini, et al., 2006; Maner et al., 2005; Roney, 2003; Wilson \& Daly, 2004). We therefore reasoned that if conspicuous displays of consumption or benevolence are costly signals that can function to attract a mate, cues that prime romantic motives should increase people's inclination to engage in such displays.

The initial experiment tested whether priming individuals with mating cues would increase their willingness to spend or help compared with people primed with neutral cues. To test this possibility, participants in the mating condition were first primed with photographs of desirable opposite-sex individuals. Participants then indicated how much money they would spend on various conspicuous purchases and how many hours they would volunteer at various prosocial organizations. Given the literature on sex differences in mate choice, we generated several specific predictions. Because women value wealth and status in a mate more than men do (Buss, 2003; Li et al., 2002), we predicted that a mating prime would increase conspicuous consumption primarily for men. For blatant benevolence, previous findings lent themselves to two competing hypotheses: A romantic prime could produce an increase in helping for both women and men, or it could produce an increase in helping for women but not for men.

\section{Method}

\section{Participants}

One hundred fifty-nine participants ( 89 men and 70 women) were recruited from introductory psychology classes as partial fulfillment of their class requirement. All participants came to the laboratory in groups of 2-6 and were each seated between partitions at a computer. The mean age for women was 18.7 years ( $S D$ $=.97)$, and the mean age for men was 19.1 years $(S D=1.58)$.

\section{Design and Procedure}

The overall design of the experiment was a 2 (Participant Sex) $\times 2$ (Motivation: Mating vs. Control) $\times 2$ (Behavior: Consumption vs. Benevolence) mixed-factorial design. Sex and Motivation were between-participants factors, whereas Behavior was a within-participants factor, meaning that everyone answered questions regarding both spending and helping. At the beginning of the study, half of the participants were exposed to mating-related cues while the other half were exposed to cues unrelated to mating. Participants then indicated how much money they would spend on five types of conspicuous purchases and how many hours they would help at five prosocial community organizations.
Mating induction. To induce a romantic mindset in the participants, we displayed the photographs of three attractive oppositesex individuals on the participants' computer screen (see Griskevicius, Cialdini, \& Kenrick, 2006; Roney, 2003; Wilson \& Daly, 2004). Participants were asked to select the person whom they thought was the most desirable romantic partner, and, after making their selection, to imagine that they were preparing to go on a first date with this individual. They were to spend up to 3 min writing on the computer about their idea of the perfect first date with the person they selected.

Control participants underwent a similar procedure devoid of any romantic connotations. They saw a photograph of an ordinary street with several buildings and were asked to imagine being on that street. They then spent up to 3 min writing about their idea of the most pleasant weather conditions in which to walk around and look at the buildings. After the manipulation, the computer randomly determined whether participants responded first to the consumption or benevolence items (see below). The order of the questions within each set was randomized.

Consumption measures. To ascertain spending preferences, we gave the participants the following instructions: "Imagine that you have \$5,000 in your bank account and that you're considering buying a few new things. We'd like to know how much money you would consider spending on each type of purchase." Participants indicated how much money they would consider spending on five items that might be purchased by either men or women-(a) a new car, (b) a new watch, (c) taking a group of friends out to dinner, (d) a new cell phone, and (e) a nice vacation to Europe-and where each purchase could conspicuously convey one's resources. Participants responded on an 11-point scale for each item, with each point on the scale representing a specific dollar amount. Each item had a different dollar range-watch (\$25-\$275), dinner (\$50$\$ 300)$, cell phone (\$25-\$275), European vacation $(\$ 500-\$ 3,000)$, car $(\$ 5,000-\$ 50,000+)$ — but the scale increments remained constant for each item.

Benevolence measures. To ascertain willingness to help, we gave the participants the following instructions:

\footnotetext{
Imagine that you have $60 \mathrm{hr}$ of free time a month. These $60 \mathrm{hr}$ include some of your evenings and parts of your weekends. We'd like to know how much of this time you would consider spending doing volunteer work at some organizations in your community. That is, although you would only volunteer at one place, we'd like to know how many hours each month you would consider volunteering there.
}

Participants then indicated how much time they would consider volunteering to (a) help at a homeless shelter, (b) help build housing for poor families, (c) help teach underprivileged youths to read, (d) be a Big Brother or Sister, or (e) help at a children's hospital. Participants responded to each item on an 11-point scale, where each point represented a specific amount of time across the scale $(0-50 \mathrm{hr}$ in units of $5 \mathrm{hr})$.

Motivational booster. After responding to the initial set of consumption or benevolence items, all participants underwent a "booster shot" to ensure that they were still in a romantic or in a control frame of mind. The boosters were procedurally identical to the original prime, except that they consisted of photographs of different attractive individuals or buildings. After the booster, participants responded to the counterpart set of benevolence or consumption questions. 
Cover story. To decrease potential suspicion and possible demand characteristics, we devised a cover story. Participants were told that they were going to take part in three unrelated studies in the current session (i.e., rate photographs for future studies, write stories to examine their visualization ability, and answer survey questions about various preferences). The cover story noted that participants in the past have become bored when working on each study without a break (e.g., rating all of the photographs at once), so participants were told that each study would be split up into different sections throughout the session, so people wouldn't have to do the same thing over and over. Participants were also told that the various parts of the studies would be presented in random order chosen by the computer.

Because half of the participants answered one set of the dependent measures (e.g., the consumption items) immediately after the motive induction, whereas the other half answered the same items after the motivational booster, we checked whether the initial manipulation and the booster had different effects: As expected, no order effects emerged, indicating that the initial manipulation and the booster produced similar effects.

\section{Results and Discussion}

Consistent with predictions, an omnibus repeated-measures analysis of variance (ANOVA) indicated a three-way interaction between Sex, Motivation, and Behavior, $F(1,155)=4.41, p=$ .037 (see Figure 1). To examine the specific hypotheses of the study, we performed a series of planned contrasts.

\section{Consumption}

As seen in Figure 1, men in the mating condition spent more money than men in the control condition, $F(1,87)=3.82, p=$ $.053, \eta^{2}=.042$. However, a romantic prime had no effect on women's spending $(p=.95)$. Thus, as predicted, a romantic motive led men but not women to increase their spending on conspicuous purchases.

\section{Benevolence}

As seen in Figure 1, women in the mating condition were more helpful than women in the control condition, $F(1,68)=7.10, p=$ $.010, \eta^{2}=.095$. However, the mating prime had no influence on men's helping ( $p=.68$ ). Thus, consistent with the latter hypothesis, a mating motive led women but not men to be more helpful.

\section{Study 2}

According to costly signaling theory, a display of a desirable characteristic is only useful if it can be observed, meaning that the expenditure of economic resources, time, or energy should be focused on displays that are likely to be seen and to influence one's reputation (Hardy \& Van Vugt, 2006; Smith \& Bird, 2000). Thus, if displays of benevolence function as costly signals for women, a mating goal should not make women more helpful per se; it should instead produce an increase in the desire to appear more helpful in public. Similarly, if displays of consumption function as costly signals for men, a mating goal should not lead men to spend more

\section{CONSUMPTION}
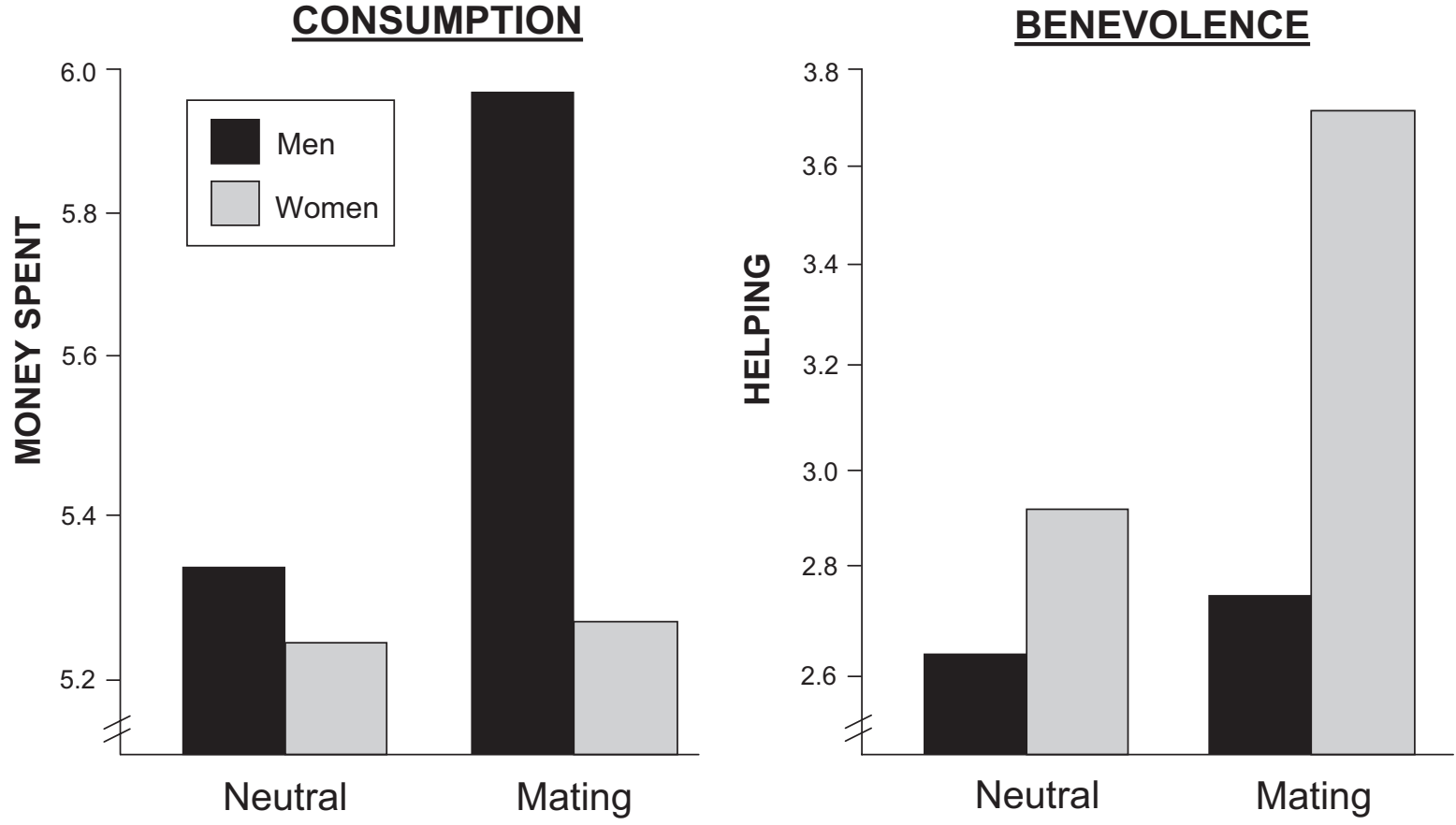

\section{ACTIVE MOTIVE}

Figure 1. The influence of romantic motives on men's and women's conspicuous consumption and blatant benevolence (Study 1). 
money on just any purchase; it should instead increase spending primarily on those purchases that can effectively act as public displays of wealth to others.

Study 2 tested whether inducing romantic motives would influence consumption and benevolence when such behaviors were conspicuous versus inconspicuous. In line with findings of Study 1 , we predicted that while a romantic motive should increase men's spending on conspicuous products-relatively luxurious and wasteful purchases that can easily be observed in public - the same romantic motive should not increase men's spending on inconspicuous products - in this case, necessities that are usually consumed in private. Similarly, we predicted that while a romantic motive should increase women's benevolence when it was conspicuous - when it was blatantly social and easily observable-the same romantic motive should not increase women's helping when it is unlikely that others would observe the behavior.

\section{Method}

\section{Participants}

One hundred sixty-eight participants ( 73 men and 95 women) were recruited from introductory psychology classes as partial fulfillment of their class requirement.

\section{Design and Procedure}

The overall design of the experiment was a 2 (Participant Sex $) \times 2$ (Motivation: Mating vs. Control) $\times 2$ (Behavior: Consumption vs. Benevolence) $\times 2$ (Conspicuousness: Conspicuous vs. Inconspicuous) mixed-factorial design. Sex and Motivation were between-participants factors, while Behavior and Conspicuousness were within-participants factors, meaning that everyone answered all questions about spending and helping. The general procedure of the study was similar to that of Study 1 with two exceptions: We induced mating motivation using written scenarios instead of photographs in hopes of increasing confidence in the conceptual framework; the study also included additional items measuring inconspicuous benevolence and consumption.

Mating induction. To induce a mating state, we asked the participants to read a romantic scenario on the computer. In the scenario, participants imagined meeting a highly desirable person of the opposite sex and spending a romantic afternoon with that person. They then imagined having a romantic dinner and pleasant conversation later that evening, finding themselves strongly motivated to romantically pursue the person. In the control scenario, participants imagined getting ready to go to a much-anticipated concert with a same-sex friend. The control scenario ended as the person heads off in a great mood anticipating a delightful musical experience.

To test whether the mating scenario elicited romantic feelings and desires, we collected self-report measures from an additional 33 men and 74 women. After reading either the romantic or the control scenario, participants indicated to what extent they were experiencing (a) romantic arousal, (b) sexual arousal, (c) a desire to have a romantic partner, and (d) a desire to have others be attracted to them. Responses were provided on a 7-point scale with endpoints 1 (not at all) and 7 (very much). Compared with the control scenario, the mating scenario elicited a higher level of romantic arousal $(M s=5.23$ vs. $1.21 ; p<.001)$ and sexual arousal $(M s=4.14$ vs. $1.37 ; p<.001)$; these data indicate that the scenarios induced a goal-based construct, given that sexual arousal is a motivational state. Moreover, the mating scenario elicited a stronger desire to have a romantic partner $(M s=5.45$ vs. $1.29 ; p<$ $.001)$ and a stronger desire to have others be attracted to the reader $(M s=5.20$ vs. $1.32 ; p<.001)$. There were no sex differences for any of the ratings (all $p \mathrm{~s}>.35$ ), meaning that the mating scenario appeared to elicit fairly strong romantic emotions and motivations about equally for both men and women. ${ }^{1}$

Consumption measures. Participants again indicated how much money they would spend on the same public wealthdisplaying purchases as in Study 1 (i.e., new car, new watch, and so forth), which constituted the five conspicuous items. In addition, participants indicated their spending on five different types of inconspicuous purchases (that sometimes included an example of a specific good in that category): (a) basic toiletries (e.g., tissues), (b) household medication (e.g., headache medicine), (c) a bedroom alarm clock, (d) kitchen staples (e.g., salt), and (e) household cleaning products (e.g., tile cleaner). Instead of asking participants about specific dollar amounts that they would consider spending on each purchase, we asked them following question: "Compared with the average student at your university, please indicate how much money you would want to spend on ...." Responses were given on a 9-point scale with the following labels: 1 (much less than the average student), 5 (about average), and 9 (much more than the average student).

Pilot testing with the same group of 33 men and 74 women as above indicated that people clearly understood the differences between the conspicuous and inconspicuous purchases. In providing responses on 7-point scales, participants indicated that they were significantly more likely to talk about and show off the conspicuous compared with the inconspicuous purchases $(M s=$ 5.61 vs. $2.21 ; p<.001)$. The conspicuous products were also rated as less of a necessity and more of a luxury than the inconspicuous items $(M s=5.67$ vs. $1.43 ; p<.001)$. There were no sex differences in any of these ratings.

Benevolence measures. Participants again indicated their willingness to help in the same five publicly helpful situations described in Study 1 (i.e., homeless shelter, being a Big Brother or Sister, and so forth), which constituted the five conspicuous benevolence items. Participants also indicated their willingness to help in five inconspicuous situations: (a) spend an afternoon each weekend picking up trash alone at the park, (b) take much shorter showers in order to conserve water, (c) put money into strangers' parking meters when time had expired, (d) mail a letter that someone had dropped on the way to the post office, and (e) go to the library to drop off a found library book in the drop box. Instead of participants being asked about the number of hours that they

\footnotetext{
${ }^{1}$ We actually included two types of romantic scenarios. Although the scenarios were highly similar to each other, one subtly noted the short-term nature of the romantic relationship, whereas the other noted the long-term nature of the relationship. Despite expectations that the short-term versus long-term elements would produce different degrees of romantic interest from men and women, the scenarios elicited nearly identical levels of sexual arousal and desire from both sexes. Moreover, because each scenario influenced the dependent measures in a highly similar fashion, the two scenarios were combined in the analyses.
} 
would consider helping, they were asked the following: "Compared with the average student at your university, how willing would you be to ...." Responses were given on a 9-point scale with the same labels described for the consumption items above.

Pilot testing with the same group of 33 men and 74 women revealed that people clearly understood the difference between the conspicuous and inconspicuous benevolence items. Responding on 7-point scales, participants indicated that they were more likely to tell someone they knew about the conspicuous versus inconspicuous acts $(M s=4.88$ vs. $3.48 ; p<.01)$. The conspicuous acts were also perceived as much more public than the inconspicuous acts $(M s=5.67$ vs. $2.37 ; p<.001)$. There were no sex differences in these ratings.

Motivational booster. As in Study 1, there was a motivational booster after participants answered the randomly assigned first set of questions about consumption or benevolence. In the booster for the romantic condition, participants imagined themselves back in the romantic scenario that they had read earlier and were given up to $3 \mathrm{~min}$ to write about the characteristics they would desire in their ideal mate. In the control condition, they were asked to think back to the scenario they had read earlier and to write about the characteristics of the anticipated concert venue.

Cover story. As in the first study, a cover story was used to prevent potential suspicion or possible demand characteristics. Unlike in Study 1, however, the cover story consisted of telling participants that we were interested in their various preferences and behaviors. However, to reduce extraneous bias in the study, we needed to make sure that everyone was "on the same page" by having everyone read a standard scenario before we could ask the survey questions. Thus, participants were led to believe that everyone was reading the same scenario and that the nature of the scenario was irrelevant to the study as long as it served to focus everyone on the same thing. Consistent with the cover story, participants were told that the purpose of the booster was to bring everyone back to an "equivalent frame of mind" by focusing them back on the scenario they had read earlier before going further in the study. As in Study 1, no order effects emerged regarding whether participants responded to the consumption or the benevolence items after the initial motive manipulation or after the booster, indicating that the motive manipulation and the booster produced similar effects.

\section{Results}

Consistent with predictions, an omnibus repeated-measures ANOVA indicated a four-way interaction among Sex, Motivation, Behavior, and Conspicuousness, $F(1,163)=15.12, p<.001$ (see Figures 2 and 3 combined). To examine the specific hypotheses of the study, we performed a series of planned contrasts.

\section{Consumption}

Replicating Study 1, men in the mating condition spent more money on conspicuous products compared with men in the control condition, $F(1,71)=4.83, p=.031, \eta^{2}=.064$ (see Figure 2 ). By contrast, a romantic motive actually reduced men's spending on inconspicuous purchases, $F(1,71)=4.04, p=.048, \eta^{2}=.054$. Thus, a mating motive did not simply lead men to spend more in general, but it led them to strategically spend more only on conspicuous products. For women, romantic motives did not have any significant influence on spending in either condition (all $p \mathrm{~s}>$ $.67)$.

\section{Benevolence}

Replicating Study 1, women in the romantic condition helped more on the conspicuous items compared with women in the control condition, $F(1,93)=6.37, p=.013, \eta^{2}=.064$ (see Figure 3 ). In contrast, a mating motive did not influence women's helping when the help was inconspicuous $(p=.83)$. Thus, a mating motive did not simply lead women to be more helpful in general, but it led them to be more helpful only in public and conspicuous situations. Romantic motives had no effect on men's helping in either condition (all $p \mathrm{~s}>.28$ ), and women were generally more helpful than men across conditions, $F(1,164)=$ 9.39, $p=.003, \eta^{2}=.054$.

\section{Discussion}

Using different methodologies to induce mating goals, different control conditions, and different phrasing for the dependent measures, we found support from the first two studies for the hypotheses that men's conspicuous displays of consumption and women's blatant displays of benevolence can function tactically as costly signals in attracting mates. Specifically, a romantic desire led men to increase their spending on conspicuous purchasesproducts that are luxurious, relatively frivolous, and publicly consumed. But a romantic desire did not lead men to spend more on inconspicuous purchases-products that are necessities and are generally consumed in private. In fact, mating motives actually caused men to spend less money on inconspicuous products leading them to be penny-wise but pound-foolish, possibly because mating goals encouraged men to divert their resources from necessities to conspicuous displays. For women, a romantic desire increased blatant benevolence-helping that is social and public. However, mating motives did not increase women's inconspicuous helping-helping that is nonsocial and unlikely to be observed by one's friends or acquaintances.

Although previous work has shown that resources and prosociality are desirable traits in mates, it is important to note that romantic motives did not merely lead men to spend more money and lead women to be more prosocial. Instead, for both men and women, romantic motives triggered highly strategic and sexspecific self-presentations consistent with costly signaling theory, whereby men signaled their resources and women signaled their prosocial virtues.

Notably, the specific boosts triggered by the mating primes occurred despite there being no actual incentive for men to appear wealthier or for women to appear more helpful. That is, the romantic cues were photographs or imaginary scenarios, and participants could not actually impress a romantic partner with their displays.

\section{Study 3}

Although the findings so far are consistent with the literature on mate preferences, it is somewhat puzzling that mating motives did not increase men's displays of benevolence. Recall that Study 1 


\section{CONSUMPTION}
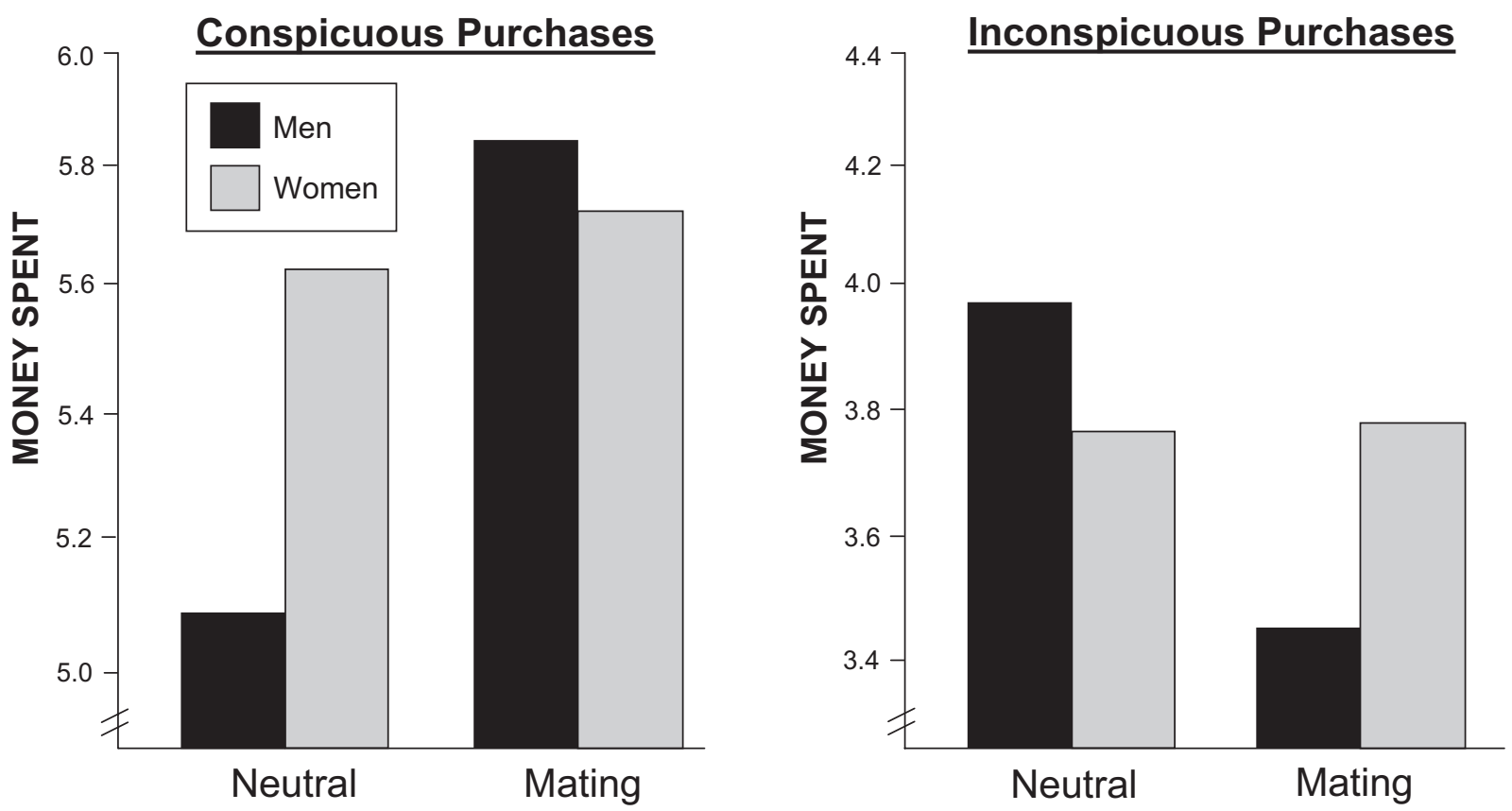

ACTIVE MOTIVE

Figure 2. The influence of romantic motives on men's and women's spending depending on whether the consumption is conspicuous versus inconspicuous (Study 2).

contained an unsupported competing hypothesis stating that romantic goals could have led men to display helpfulness. This lack of a male benevolence boost is consistent with findings that helpfulness, per se, does not always enhance a man's desirability (Kelly \& Dunbar, 2001). However, other findings suggest that men do often perform conspicuous acts of helpfulness: Men are 10 times more likely than women, for example, to be the recipients of Carnegie Hero Medals, which are awarded for extreme acts of heroism (Johnson, 1996).

One possibility is that men's displays of heroism are simply not linked to mating but are instead linked to status or some other motivation. However, the display of heroic behaviors would certainly be consistent with costly signaling theory. In addition to conveying one's helpfulness, a heroic act can also signal health, vigor, and willingness to act courageously (Hawkes \& Bird, 2002). Indeed, such heroic signaling has been observed in other animal species. For example, Zahavi and Zahavi (1997) reported that in Arabian babblers, a social bird species, males compete to be the group's "sentinel," who watches for predators from tree-tops and thereby puts himself at the highest risk of being eaten. In line with costly signaling theory, the more time a male spends as a sentinel, the more he receives preferential access to mates. Similarly in humans, men who display heroic helpfulness are also preferred as romantic partners (Farthing, 2005; Kelly \& Dunbar, 2001). Thus, mating goals might increase men's blatant benevolence if their helping behavior could also signal heroic qualities. For women, however, heroism and risk-taking involve a less favorable ratio of benefits to costs (e.g., endangering offspring who depend on the mother's proximity, Taylor et al., 2000) and might therefore not yield an equivalent mating advantage

In the first two studies, romantic motives increased altruistic displays for women, but they did not produce a parallel increase in women's conspicuous consumption. Although the notion that women do not flaunt their wealth to attract a mate is consistent with our predictions, our earlier findings suggest that there may be at least one context in which romantic motives would lead women to spend more money: when that money goes toward helping other people in an obvious way. For instance, although in the United States, women as a group earn less money for every dollar that men earn, the percentage of women who give to charity is actually greater (Coffman, 2000), and almost half of the top philanthropists in the United States are women (Chronicle of Philanthropy, 2006). Thus, while romantic motives may not increase women's spending when purchases serve mainly to signal wealth, they might increase spending for both men and women when the spending is conspicuous and can convey both one's helpfulness and one's financial generosity.

In Study 3, we tested whether romantic motives might influence benevolence and consumption in two specific contexts. First, we examined how romantic motives influence blatant benevolence when the behavior could signal either nonheroic or heroic benevolence. We predicted that mating goals would once again not influence men's nonheroic helpfulness (as in Studies 1 and 2), but they would increase men's heroic helpfulness. Second, the study tested how romantic motives influence conspicuous consumption when spending could either signal only wealth or could signal both 


\section{BENEVOLENCE}
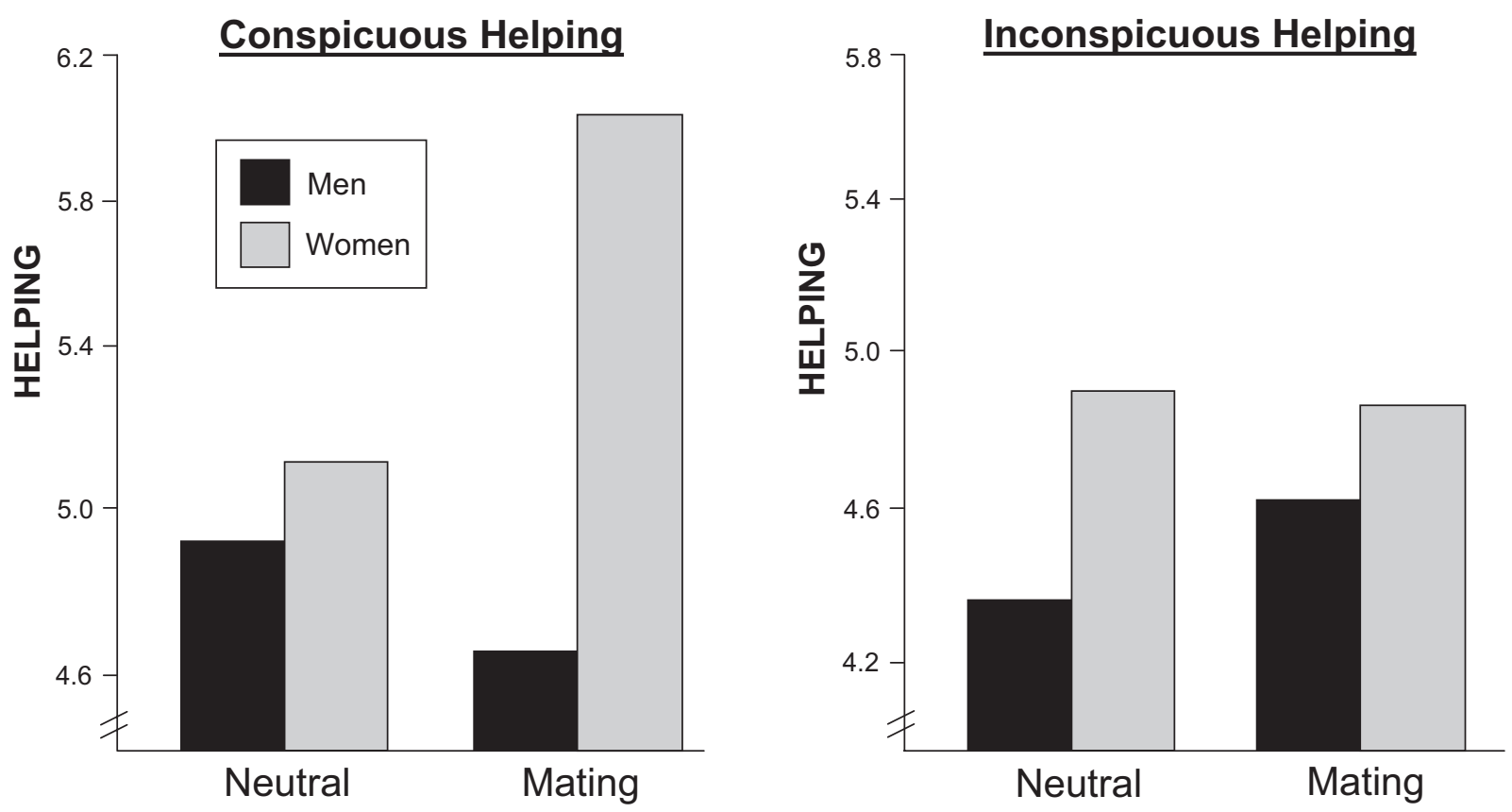

ACTIVE MOTIVE

Figure 3. The influence of romantic motives on men's and women's benevolence depending on whether helping is conspicuous versus inconspicuous (Study 2).

helpfulness and financial generosity. We predicted that while mating goals would increase wealth-related consumption only for men (as in Studies 1 and 2), they should increase conspicuous financial generosity for both men and women.

Finally, the study examined whether romantic motives may differentially influence behavior depending on a person's sociosexual orientation-one's inclination toward pursuing sex without commitment versus pursuing monogamous relationships as measured by the Sociosexual Orientation Inventory (SOI; Simpson \& Gangestad, 1991, 1992). Given some previous findings (Sundie, Kenrick, Griskevicius, \& Tybur, 2007), we expected that romantic motives might especially increase displays among "unrestricted" men-those men who score high on the SOI, indicating a proclivity to pursue multiple sexual partners.

\section{Method}

\section{Participants}

One hundred ninety-nine participants (103 men and 96 women) were recruited from introductory psychology classes as partial fulfillment of their class requirement.

\section{Design and Procedure}

The overall design of the experiment was a 2 (Participant Sex $) \times 2$ (Motivation: Mating vs. Control) $\times$ (Benevolence: Helpful vs. Heroic) $\times 2$ (Consumption: Wealth vs. Generosity) mixed design. Sex and Motivation were between-participants fac- tors, and Benevolence and Consumption were within-participants factors, meaning that everyone answered all question regarding spending and helping. The general procedure of the study was very similar to that of Study 2, including use of the same scenarios to prime romance, the same motivation booster, the same manner of phrasing the behavioral questions, and the same cover story. The only additions to the current study were the inclusion of heroic helping and charitable consumption items and the measurement of participants' sociosexual orientation.

Heroic benevolence measures. In addition to obtaining responses to the original five blatant (but nonheroic) benevolence items from Studies 1 and 2 (i.e., working at a homeless shelter, being a Big Brother or Sister, and so forth), participants also indicated their willingness to help in five heroic situations: (a) dive into icy water after a stranger falls from a boat in a storm, (b) run into a burning building in which someone is trapped, (c) distract a grizzly bear that is attacking a stranger, (d) confront two armed burglars who are robbing a house, and (e) swim out into the ocean to help a person being dragged out by the undercurrent.

Generous consumption measures. In addition responding to the original five conspicuous consumption items from Studies 1 and 2 (i.e., new car, European vacation, and so forth.), participants also indicated their willingness to spend money on the following publicly helpful acts: (a) donate money to natural disaster victims at a booth on campus, (b) leave an extra large tip when at dinner with friends after noticing that others are not leaving tips, (c) bid on something that they do not need at a public auction where proceeds go to help children with life-threatening illnesses, (d) 
give money to a charity booth at the mall that purchases holiday gifts for poor families, and (e) buy dinner for a homeless family who approach them when they are leaving a restaurant with a group of friends.

\section{Results}

To examine the specific hypotheses of the study, we performed a series of a priori lower order interactions and planned contrasts.

\section{Benevolence}

Consistent with predictions, a three-way interaction emerged among Sex, Motivation, and Benevolence Type, $F(1,195)=3.31$, $p=.071, \eta^{2}=.017$ (see Figure 4). As in the first two studies, women in the romantic condition were more helpful in volunteer situations than women in the control condition, $F(1,94)=4.57$, $p=.035, \eta^{2}=.046$. Women were also more helpful than men across conditions, $F(1,195)=11.81, p=.001, \eta^{2}=.057$, and a romantic desire again had no influence on men's helpfulness ( $p=$ $.75)$.

For the heroic items, there was a main effect of Sex, whereby men were more willing to be heroic across both motive conditions, $F(1,195)=57.36, p<.001, \eta^{2}=.28$. However, in line with predictions, men in the romantic condition were significantly more helpful on the heroic items compared with men in the control condition, $F(1,101)=4.84, p=.030, \eta^{2}=.046$. For women, a romantic prime did not influence heroic helping ( $p=.67$ ).

\section{Consumption}

As seen in Figure 5, men in the mating condition again spent more on conspicuous purchases than did men in the control condition, $F(1,101)=4.31, p=.040, \eta^{2}=.041$, but a romantic motive did not influence women's spending on these items ( $p=$ .86). However, when conspicuous spending was related to helping, a romantic prime led both men and women to spend more money than participants in the control condition, $F(1,195)=10.64, p=$ $.001, \eta^{2}=.052$. Nevertheless, women were still more likely to be conspicuously charitable across both generous spending conditions, $F(1,195)=9.38, p=.003, \eta^{2}=.046$.

\section{Effects of Sociosexual Orientation}

SOI generally did not have a significant influence on men's or women's benevolence or consumption in the control conditions or on how such behaviors were influenced by the mating primes. However, there were two specific instances in which SOI produced notable findings - in both cases for men.

First, SOI affected how romantic motives influenced men's financial generosity. Although there were no differences in financial generosity between high and low SOI men in the control condition using a median split $(p=.92)$, mating motives led to a significant increase in financial generosity for unrestricted menthose men inclined to pursue short-term mating strategies, $F(1$, 46) $=7.49, p=.009, \eta^{2}=.14$. Although restricted men-those less inclined toward having sex without commitment-also

\section{BENEVOLENCE}
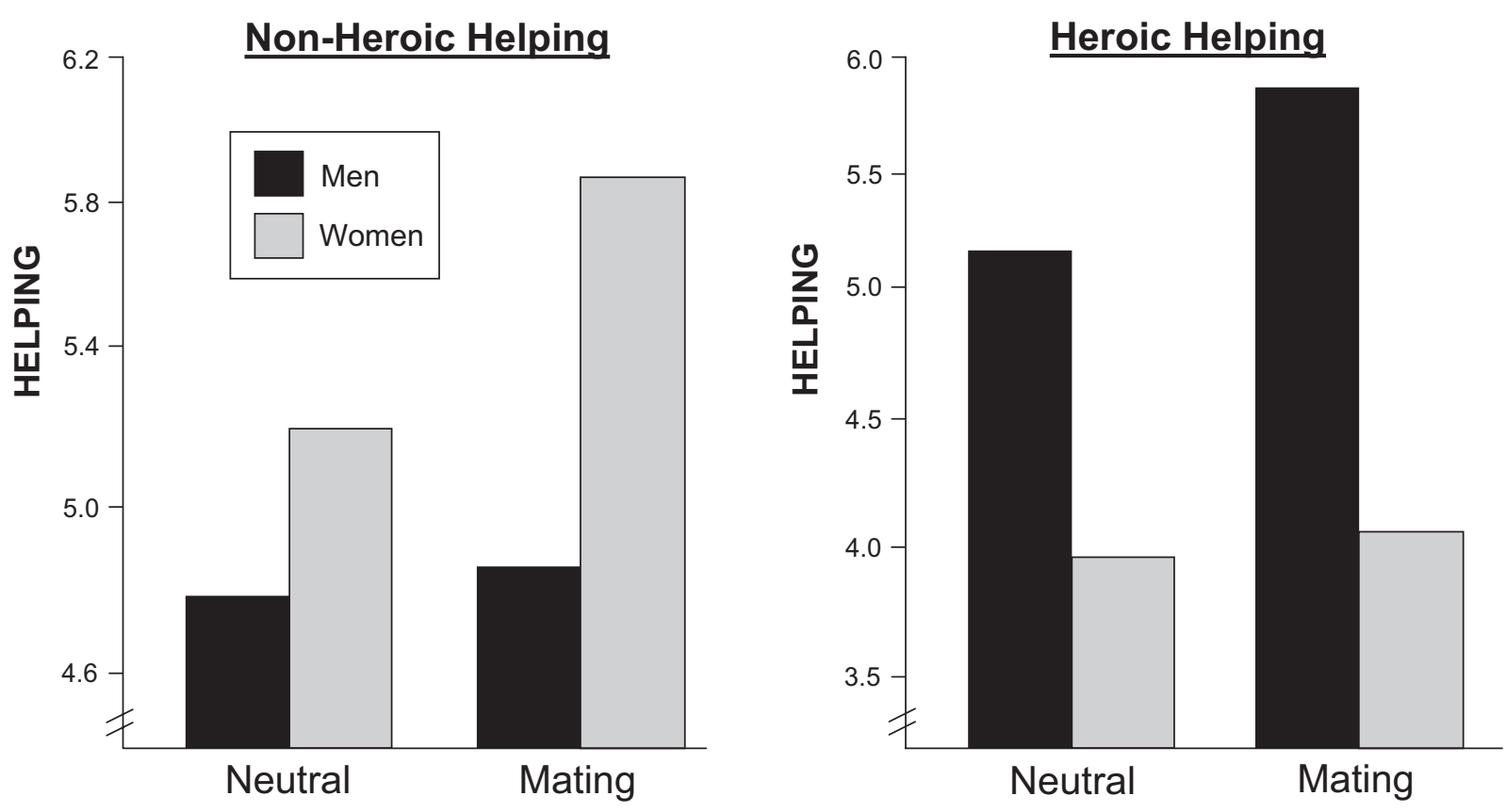

\section{ACTIVE MOTIVE}

Figure 4. The influence of romantic motives on men's and women's benevolence depending on whether the helping is heroic versus nonheroic (Study 3). 


\section{CONSUMPTION}

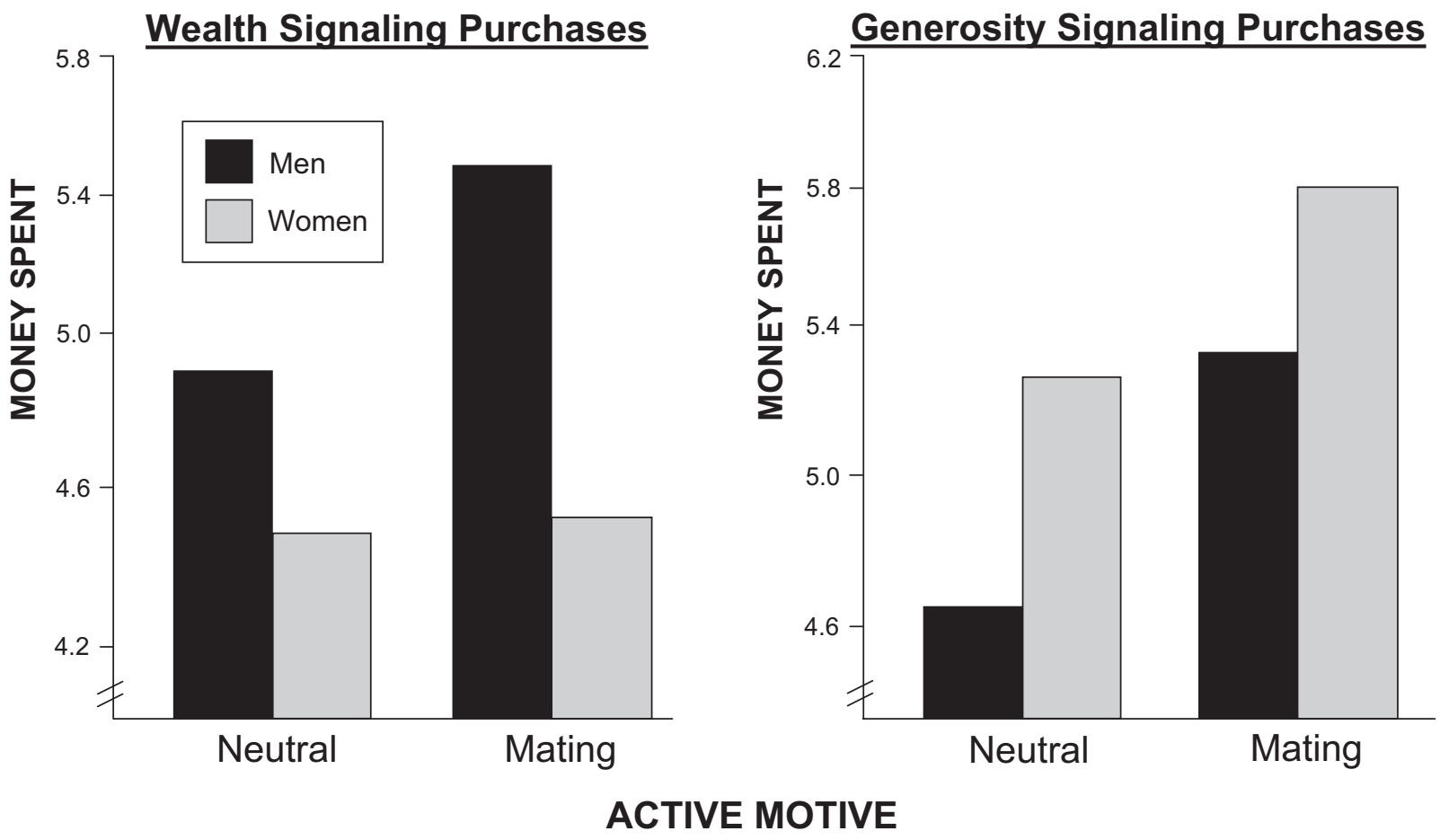

Figure 5. The influence of romantic motives on men's and women's consumption depending on whether spending signals wealth versus financial generosity (Study 3 ).

showed a moderate increase in financial generosity in the romantic condition, this difference did not approach significance $(p=.18)$.

Second, sociosexual orientation affected how romantic motives influenced men's heroic helping. Although we found no differences in heroic helping between high and low SOI men in the control condition using a median split ( $p=.71)$, a romantic prime produced a sizable boost in heroism for unrestricted men, $F(1$, 46) $=11.31, p=.002, \eta^{2}=.20$. Conversely, a romantic motive produced no difference in the heroic behavior of restricted men $(p=.76)$.

\section{Discussion}

The results of Study 3 revealed two theoretically meaningful contexts in which romantic motives boosted men's blatant benevolence and boosted women's conspicuous consumption. First, although romantic motives did not lead men to be more helpful in general, they did lead men to be more helpful in situations that could signal heroism. That is, when men's helpfulness could simultaneously allow them to display courage and strength, a romantic motive caused a boost in such behavior. This result is consistent with findings that heroic men are preferred as mates (Farthing, 2005; Kelly \& Dunbar, 2001) and with the notion that heroic displays can function as costly signals of helpfulness and courage. These findings, however, are the first of which we are aware to indicate that romantic contexts can actually trigger such tactics for men.
Although romantic motives once again did not lead women to conspicuously consume, they did lead both men and women to increase their conspicuous financial generosity-that is, to spend more money in publicly charitable ways. This finding is congruent with the fact that both men and women behave philanthropically. However, the first three studies together suggest that men and women may differ in the characteristics they signal through their philanthropic acts (at least to potential mates): Men's philanthropy may signal mostly wealth, whereas women's philanthropy may signal mostly helpfulness.

\section{Study 4}

Although the first three studies show an empirically clear and theoretically consistent relationship among romantic motives, blatant benevolence, and conspicuous consumption, one piece of the puzzle in the current research remains poorly understood: Although mating goals led men to be more heroically helpful in Study 3, it is still unclear why mating motives did not increase men's nonheroic helpfulness. After all, kindness and agreeableness are desirable characteristic in both women and men (Botwin et al., 1997; Brase, 2006; Buss, 1989; Graziano et al., 1997), and men engage in all sorts of helpful acts, including nonprofit volunteer work. Given this discrepancy, we sought in Study 4 to explore two theoretically derived nonheroic helping contexts in which romantic motives might trigger men to become more benevolent.

One context in which romantic motives might spur helping in men - and in women-arises when the helpful behavior could 
increase the helper's status or prestige. For example, although volunteering at a homeless shelter or working with underprivileged kids is not very prestigious, volunteering to do charitable work at the White House or rebuilding New Orleans along with professional athletes is likely to make a much more favorable impression on others. Given that people tend to strategically associate themselves with successful or prestigious others to convey a positive impression (see Cialdini, 1989; Snyder, Lassegard, \& Ford, 1986), a romantic desire might produce a boost in people's willingness to perform prestigious helpful acts because such acts could convey an impression of high status and prestige to potential mates.

A second context in which romantic motives might spur helping in men arises when the helpful act could display other desirable male traits. For example, women show a strong preference for men who are both prosocial and dominant (Green \& Kenrick, 1994; Jensen-Campbell et al., 1995; Kelly \& Dunbar, 2001; Sadalla, Kenrick, \& Vershure, 1987), suggesting that a romantic desire should cause men to be more helpful when the behavior can also signal dominance or other male-related traits, such as leadership and assertiveness (Baumeister \& Sommer, 1997; Buss, 2003). Specifically, given that romantic motives led primarily unrestricted men to behave more heroically in Study 3, romantic motives may also induce primarily unrestricted men to be more helpful when such acts could display their dominance and leadership.

Overall, in addition to including the same prosocial community organization contexts as in the first three studies, Study 4 tested whether romantic motives influence displays of blatant benevolence in two additional contexts: when the helpful acts are associated with prestige or when the helpful acts can signal dominance and leadership. We predicted that although mating motives would lead only women to display helpfulness in low-prestige or lowdominance contexts (as in the first three studies), mating motives should lead both women and men to become more benevolent in high-prestige contexts. Also, we predicted that a romantic desire should lead men-especially unrestricted men-to become more helpful when such acts could signal characteristics of dominance and leadership.

\section{Method}

\section{Participants}

One hundred sixty-eight participants (108 men and 60 women) were recruited from introductory psychology classes as partial fulfillment of their class requirement.

\section{Design and Procedure}

The overall design of the experiment was a 2 (Participant Sex) $\times 2$ (Motivation: Mating vs. Control) $\times 3$ (Benevolence: Helpful vs. Prestigious vs. Dominant) mixed-factorial design. Sex and Motivation were between-participants factors, while Benevolence was a within-participants factor, meaning that everyone answered all of the helping items. The procedure was similar to that of Study 3, except the current study included more benevolence items.

Prestigious benevolence measures. In addition to responding to the original five blatant benevolence items from Studies 1-3 (i.e., working in a homeless shelter, being a Big Brother or Sister, and so forth), participants also indicated their willingness to help in five situations associated with famous athletes, celebrities, or prestigious organizations. The specific items asked to what extent participants were willing to (a) volunteer to work with Lance Armstrong to raise money for cancer awareness, (b) volunteer with Hollywood celebrities to help grant wishes of children with terminal illnesses through the Make a Wish Foundation, (c) volunteer to work with Magic Johnson to help people with AIDS, (d) volunteer to go to Washington, DC, to help coordinate meetings between charities and White House officials, and (e) volunteer to work with professional athletes to rebuild homes in New Orleans.

Dominant benevolence measures. Participants were also asked to report their willingness to help in another set of situations that would require dominance and assertive leadership: (a) give a speech for a good cause in which they believe to a large and potentially hostile crowd, (b) lead a public protest in support of an important cause even though they could be arrested, (c) volunteer to personally negotiate with state officials to get more funding for a nonprofit organization, (d) have a public one-on-one debate with the leader of an organization whose beliefs they find offensive, and (e) be the first person to speak out publicly against something they believe to be morally wrong.

\section{Results}

Consistent with predictions, a repeated-measures omnibus ANOVA indicated a three-way interaction among Sex, Motivation, and Benevolence Type, $F(2,382)=4.31, p=.014$. To examine the specific hypotheses of the study, we performed a series of planned contrasts.

\section{Helpful Benevolence}

In keeping with the outcomes of the first three studies, women in the mating condition helped more on the original blatant benevolence items than women in the control condition, $F(1,58)=7.88$, $p=.007, \eta^{2}=.12$. Women were also more helpful than men in general, $F(1,164)=6.62, p=.011, \eta^{2}=.039$, and the mating prime again did not influence men's helping on these nonprestigious, nondominant items $(p=.48)$.

\section{Prestigious Benevolence}

As seen in Figure 6, compared with the men and women in the control condition, men and women in the mating condition were more helpful when such acts could signal status or prestige, although this effect was only marginally significant, $F(1,164)=$ $3.66, p=.058, \eta^{2}=.022$. As expected, there was no interaction between Sex and Motivation on these items $(p=.91)$.

\section{Dominant Benevolence}

As seen in Figure 6, men in the romantic condition were somewhat more likely to volunteer in situations that could indicate dominance and leadership (such as giving a speech, leading a protest, or engaging in a public debate) compared with men in the control condition, although this effect did not reach conventional levels of significance, $F(1,106)=6.26, p=.09, \eta^{2}=.027$. A closer inspection of the results showed that this increase was driven mostly by unrestricted men (as for the heroic items in Study 


\section{BENEVOLENCE}
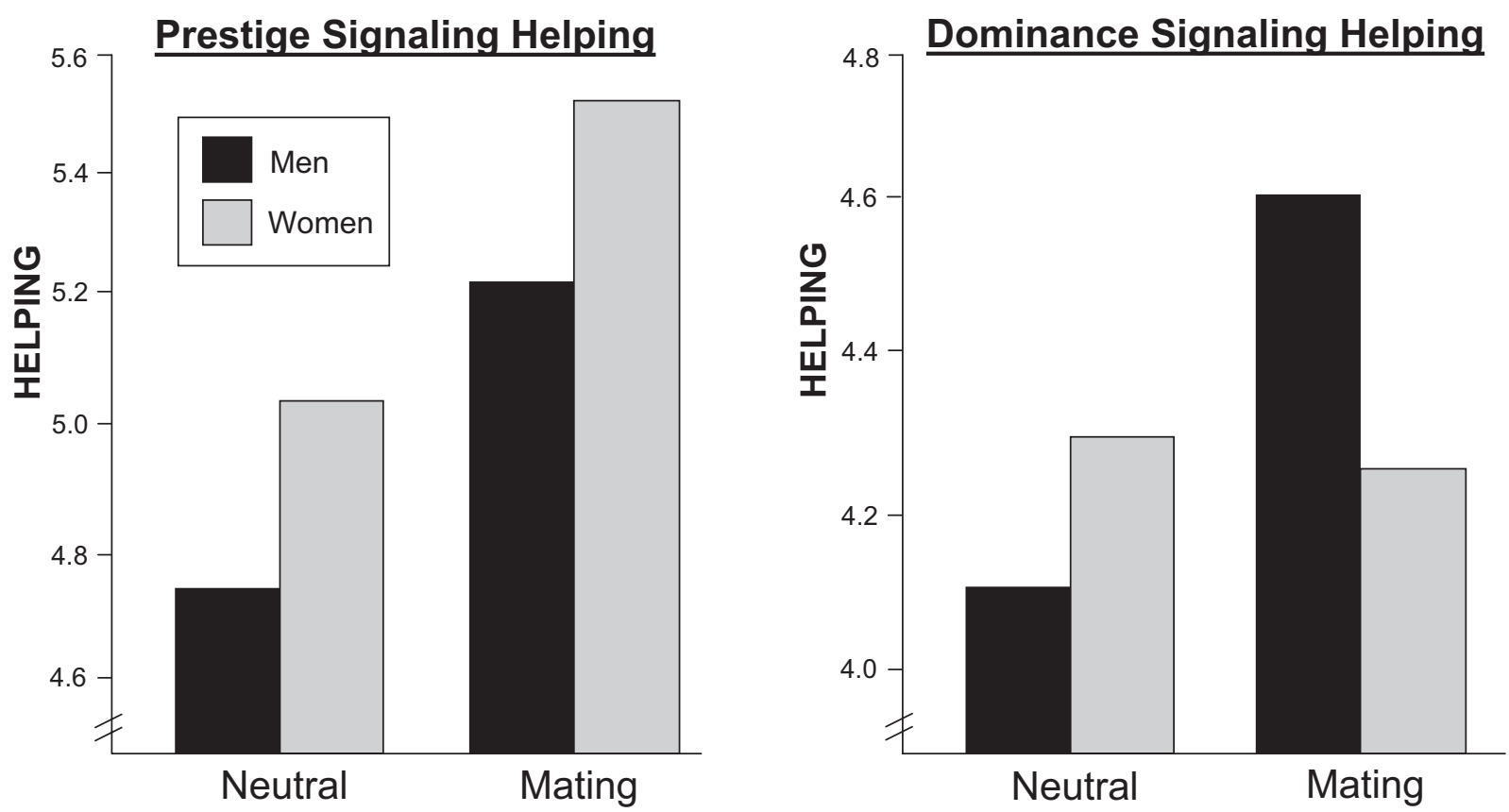

\section{ACTIVE MOTIVE}

Figure 6. The influence of romantic motives on men's and women's benevolence depending on whether helping signals prestige versus dominance (Study 4).

$3)$, who showed a stronger increase in the mating condition than unrestricted men in the control condition, $F(1,47)=3.83, p=$ $.056, \eta^{2}=.079$. Although restricted men also increased their dominant benevolence in the romantic condition, this difference did not approach significance $(p=.51)$. SOI did not influence any of the other measures, and the romantic prime had no influence on women's displays of dominant benevolence $(p=.91)$.

\section{Discussion}

The findings from Study 4 show that romantic motives can lead men to be more helpful even in some nonheroic contexts. First, mating goals led both men and women to be somewhat more helpful when the helping was prestigious. This finding is congruent with the notion that people often use indirect self-presentation tactics, such as associating with prestigious others, to be seen in a more positive light by others (see Cialdini, 1989; Snyder et al., 1986). Second, mating goals led men, especially unrestricted men, to be somewhat more helpful when the benevolent behavior could signal dominance and leadership. This finding fits with the notion that women value dominance and leadership in men (Buss, 2003; Sadalla et al., 1987) and with findings that romantic motives lead men-but not women-to conspicuously rebel against social norms to assert their individuality by not conforming (Griskevicius, Goldstein, Mortenson, Cialdini, et al., 2006). Overall, although previous findings on mate preferences may have led one to expect that romantic contexts should cause men to behave in a generally more prosocial manner, we found that mating goals actually led men to behave prosocially in a highly strategic way, whereby men became more helpful only when such helpfulness could display prestige or dominance.

\section{General Discussion}

The current research began with a basic question: Is public philanthropy related to romantic motives? We examined this question using a costly signaling framework, investigating how mating goals influence conspicuous displays of consumption and benevolence - the two key self-presentational facets of philanthropy. Although previous work on mate preferences has uncovered a variety of traits that are desired in a mate, we extended this research by showing that priming individuals with displays of photographs of attractive members of the opposite sex (Study 1) or with descriptions of romantic scenarios (Studies 2-4) elicited highly strategic, context-sensitive, and sex-specific behavioral displays. The findings were in line with research showing that men and women value somewhat different features in a mate and were consistent with costly signaling theory, marking one of the first empirical investigations of this approach in psychology.

Specifically for men, mating goals increased resource-signaling displays of conspicuous consumption, leading them to spend more money on luxurious and publicly consumed purchases. Mating motives, however, did not increase men's spending on inconspicuous products, suggesting that romantic cues did not just lead men to spend more money in general but did so in a strategic manner in line with costly signaling theory. Although a mating motive did not 
increase men's general helpfulness as might be expected from the mate preference literature, it did boost men's helpfulness when such acts could also signal men's heroic, dominant, and prestigious qualities. These findings are consistent with well-established differences in mate preferences, which show that women place a higher value on men's resource-related and dominance-related traits (e.g., Buss, 1989; Kenrick et al., 2001; Li et al., 2002; Sadalla et al., 1987).

However, whereas most previous research has suggested that wealth may be valued as a cue for future male parental investment, our work suggests that displays of wealth may also be related to signaling underlying characteristics that are correlated with wealth acquisition, such as intelligence, social skills, or the ability to compete for resources. Thus, just as peacocks' tail displays indicate that male peacocks are able to successfully absorb the cost of wasting metabolic resources on such frivolous ornaments, men's conspicuous consumption displays seem to indicate that they are successfully able to absorb the cost of wasting financial resources on frivolous products. Otherwise, if men were solely advertising parental investment ability via consumption, it would seem to be more productive for them to increase their investment in inconspicuous consumption goods that would be more useful in future family life (e.g., vacuum cleaners rather than flashy cars).

Whereas previous research has mostly focused on male tactics, our studies indicate that women also engage in strategic courtship displays in line with costly signaling theory. Specifically, mating motives increased women's helpfulness-signaling displays of benevolence, whereby women became more helpful across various public volunteer situations. Mating goals, however, did not increase women's helpfulness in private, unobservable settings, suggesting that romantic motives mostly led women to want to appear publicly more helpful. Although romantic primes did not lead women to conspicuously consume products that could display their wealth, mating primes did cause women to spend more money when the resources went to charitable causes. These findings should not be read to imply that women display more benevolence only in mating contexts; it may also be beneficial for women to advertise prosocial traits in several other domains (e.g., when trying to attract friends and allies). However, our findings suggest that mating goals are one of the factors that can induce women to act more prosocially.

\section{Motivation and Strategic Self-Presentation}

The current studies indicated that fundamental social motives, such as mate-attraction, can stimulate specific costly displays in the service of strategic self-presentation. Notably, the effects of the mating prime were obtained even when such displays could not produce any genuine social, sexual, or reproductive benefits. As suggested by other recent work (e.g., Griskevicius, Goldstein, Mortensen, Sundie, Cialdini, \& Kenrick, 2006; Maner et al., 2005; Wilson \& Daly, 2004), it is likely that the activation of fundamental social motives stimulates specific mental sets that activate a cascade of functional perceptions, cognitions, and behaviors that can occur outside of people's awareness. For example, Roney (2003) found that men report greater ambition and desire to earn money not only in the presence of desirable women but also after merely looking at photographs of such women.
It is important to note that the current framework does not imply that conspicuous consumption and blatant benevolence are sexually motivated at a conscious level. Instead, our framework implies that these behaviors are influenced by mating-related factorssuch as pictorial or verbal cues of mating opportunities, individual sex, and public observability-in ways that would be expected if these behaviors served underlying adaptive courtship functions.

\section{Alternative Explanations}

The current research was inspired by existing theories of goal activation (e.g., Chartrand \& Bargh, 2002) and costly signaling (Miller, 2000). It would no doubt be possible to derive predictions regarding benevolence, consumption, and mating from other theoretical perspectives. However, it is not clear whether any of these other perspectives would offer as parsimonious an account of the highly nuanced pattern of results obtained in this series of studies. For example, perhaps a link among helping, spending, and mating arises because of simple mechanisms of associative priming (Srull \& Wyer, 1979; see Higgins, 1996). The findings presented here, however, suggest that the associative networks involved in conspicuous displays of benevolence and consumption are different for women and men and are differentially triggered by mating motives. A functional approach to cognition is by no means an alternative to associative network models because both approaches presume that there are associative links among motivation, cognition, and behavior. However, the functional model in the current research does more than just assert that priming specific ideas will lead to the activation of associatively linked semantic and affective categories. Rather, it leads to more finely articulated predictions about the particular links between specific goals and specific cognitive and behavioral responses (Maner et al., 2005; Schaller, Park, \& Kenrick, 2007).

Similarly, a social learning model might suggest that men and women have been differentially rewarded for blatant benevolence and conspicuous consumption. However, it would seem difficult for social learning models to explain the precisely patterned results we obtained concerning mating primes, sex differences, display conspicuousness, different forms of benevolence, and sociosexuality. Also, it is not always clear whether men or women receive more reward or punishment for various forms of display. For example, boys are often encouraged to show nonheroic benevolence (e.g., "Be nice," "Share"), and girls are often encouraged to conspicuously consume (e.g., "Buy a Barbie to be popular"). Yet we found that men became more helpful in some situations and increased their conspicuous consumption in others. These contextspecific displays make sense in the light of a costly signaling theory but do not follow directly from general social learning processes alone.

A social role theory might also posit that it is part of the male role to be the provider and part of the female role to be the caregiver. Although our results are consistent with such roles, it would be difficult for social role theories to have predicted a priori why helping is part of the female role in public but not in private contexts; why men spend more money on public but not on private purchases; why men are helpful in heroic, dominant, and philanthropic contexts; why men's sociosexuality moderates some of the mating-prime effects; and why women primed for mating do not increase their spending on domestic goods to display their abilities 
as housekeepers. The fact that such context-specific displays changed as a function of activating mating motives follows most directly from a costly signaling perspective (see Saad, 2007).

Neither social role theories nor social learning theories are incompatible with evolutionary accounts, because evolutionary theorists presume that social roles and social reinforcements across societies reflect evolved adaptations in men and women and arise through an adaptive interplay of learning and evolved predispositions (Kenrick, Trost, \& Sundie, 2004; Öhman \& Mineka, 2001). We are not aware, however, of social role or social learning theorists who have offered predictions that would match the articulated pattern of results obtained here-a pattern that follows directly from considering evolved mate preferences and costly signaling.

\section{Limitations and Future Directions}

One potential limitation of the current work is that the costly behaviors in these studies did not involve real costs. However, it is important to note that in the current studies we are investigating the design features of psychological adaptations for conspicuous consumption and benevolence, not actual consumption and benevolence behavior. Nonetheless, there is reason to believe that our findings would indeed correspond to actual behaviors. Although we did not measure behaviors, for instance, our items were similar to "behavioroid" or behavioral intention measures, which in comparison to attitudes, have been shown to have a relatively strong relation to behaviors (Fishbein \& Ajzen, 1975; Petty \& Cacioppo, 1981). Participants in our studies also appear to be responding as though there was a cost and as though they had a monetary or a time budget. If this was not the case, responses should be closer to ceiling and show less variance-after all, why not say that one would be highly prosocial when it does not cost one much to do so? Moreover, Norm Li and colleagues (Li et al., 2002; Li \& Kenrick, 2006), using a budget allocation method, have found indications that men and women respond in predictably different ways when their budgets vary, suggesting that people are quite capable of make these kinds of calculations.

Whether people actually engage in costly behaviors is likely to depend on the subjectively assessed costs versus mating benefits of doing so. For example, everyone may want to display costly signals - just like all peacocks may want to grow a large and shiny tail— but not everyone will be able to afford to do so. Although our results indicate that, on average, people in specific conditions wanted to display more costly behaviors, some people under real-world constraints cannot afford the display. Related to this point, although it might be possible to fake some costly signals, modern economies are generally well organized to make such signals fairly difficult to fake; this is the job of anticounterfeiting systems (trademark and copyright laws to prevent cheap imitations of luxury branded goods), retail security systems (antishoplifting tags, mall security, debit payment systems), and credit rating agencies. In the current work, we are investigating the design features of the mating motivation system as predicted from costly signaling theory, and the fact that men's and women's calculations are influenced in different ways by the romantic manipulations is the key point of the present studies.

The current studies are also potentially limited by the variations in our manipulation of conspicuousness across several dimensions.
Conspicuous consumption differs from inconspicuous consumption in that a conspicuous good is likely to be more visible, more expensive, and more frivolous. Similarly, an act of blatant versus nonblatant benevolence is likely to be more visible, effortful, and less efficient at helping. Although our manipulations tended to confound these interrelated dimensions, it would be interesting in future work to break down the various items into their conceptual components.

Although the present work focused on the production of costly displays, future research might also examine how such costly signals are perceived by intended receivers. Our framework predicts that observers are likely to be particularly attuned to various costly signaling displays and that individuals might be adept at deciphering honest versus dishonest signals. Moreover, given that men who conspicuously consume are in fact perceived as more promiscuous (Sundie et al., 2007), future research could also explore the specific trait information and sexual strategy information conveyed by various displays (Gangestad \& Simpson, 2000)

\section{Conclusion}

The present research supports the hypothesis that blatant benevolence and conspicuous consumption are costly signaling displays that can function to attract and retain mates. These results might at first blush seem to confirm the worst suspicions of Puritans, Marxists, and Freudians, who have traditionally alleged that showy consumption and charity are narcissistic indulgences of the sexually self-deceptive bourgeoisie. However, a costly signaling framework suggests that different social norms and social policies could shift such behaviors from workaholic, shopaholic, or planetwasting consumption to more prosocial forms of display. For instance, media mogul Ted Turner once bemoaned the influence of the Forbes 400 list of richest Americans, pointing out that it discouraged the wealthy from giving away their money for fear of slipping down in the rankings (Plotz, 2006). He suggested instead that a public ranking of top philanthropists could inspire the wealthy to compete in a more beneficial way-in essence, by shifting the signaling arena from conspicuous consumption to blatant benevolence. Perhaps it was not a coincidence that just such a list - the Slate 60 - was established the same year that Ted Turner pledged $\$ 1$ billion to humanitarian relief. When asked about the reaction of his then-wife Jane Fonda to this donation, Turner fondly reminisced, "It brought tears to her eyes ... . She said, 'I'm so proud to be married to you'" (CNN Interactive, 1997).

\section{References}

Alexander, R. D. (1979). Darwinism and human affairs. Seattle, WA: University of Washington Press.

American Association of Fundraising Counsel. (2005). Giving USA. Indianapolis, IN: Author.

Axelrod, R., \& Hamilton, W. D. (1981). The evolution of cooperation. Science, 211, 1390-1396.

Barrett, L., Dunbar, R., \& Lycett, J. (2002). Human evolutionary psychology. Princeton, NJ: Princeton University Press.

Batson, C. D. (1998). Altruism and prosocial behavior. In D. T. Gilbert, S. T. Fiske, \& G. Lindzey (Eds.), The handbook of social psychology (Vol. 2, 4th ed., pp. 282-316). Boston: McGraw-Hill.

Baumeister, R. F., \& Sommer, K. L. (1997). What do men want? Gender 
differences and two spheres of belongingness. Psychological Bulletin, 122, 38-44.

Berkowitz, L. (1972). Social norms, feelings, and other factors affecting helping behavior and altruism. In L. Berkowitz (Ed.), Advances in experimental social psychology (Vol. 6, pp. 63-108). New York: Academic Press.

Bird, R., \& Smith, E. A. (2005). Signaling theory, strategic interaction, and symbolic capital. Current Anthropology, 46, 221-248.

Boone, J. L. (1998). The evolution of magnanimity: When is it better to give than to receive? Human Nature, 9(1), 1-21.

Botwin, M., Buss, D. M., \& Shackelford, T. K. (1997). Personality and mate preferences: Five factors in mate selection and marital satisfaction. Journal of Personality, 65, 107-136.

Brase, G. L. (2006). Cues of parental investment as a factor in attractiveness. Evolution and Human Behavior, 27, 145-157.

Bugental, D. B. (2000). Acquisition of the algorithms of social life: A domain-based approach. Psychological Bulletin, 126, 187-219.

Burnstein, E., Crandall, C., \& Kitayama, S. (1994). Some neo-Darwin decision rules for altruism: Weighing cues for inclusive fitness as a function of the biological importance of the decision. Journal of Personality and Social Psychology, 67, 773-789.

Buss, D. M. (1989). Sex differences in human mate preferences: Evolutionary hypotheses tested in 37 cultures. Behavioral Brain Sciences, 12, $1-49$.

Buss, D. M. (2003). The evolution of desire: Strategies of human mating (2nd ed.). New York: Basic Books.

Buss, D. M., \& Schmitt, D. P. (1993). Sexual strategies theory: An evolutionary perspective on human mating. Psychological Review, 100, 204-232.

Cable News Network (CNN) Interactive. (1997, September 19). Ted Turner donates $\$ 1$ billion to "U. N. causes." Retrieved April 17, 2007, from http://edition.cnn.com/US/9709/18/turner.gift/

Chartrand, T. L., \& Bargh, J. A. (2002). Nonconscious motivations: Their activation, operation, and consequences. In A. Tesser, D. Stapel, \& J. Wood (Eds.), Self and motivation: Emerging psychological perspectives (pp. 13-41). Washington, DC: American Psychological Association.

Chronicle of Philanthropy. (2006, February 20). The 2005 Slate 60. Retrieved April 17, 2007, from http://www.slate.com/id/2136397/

Cialdini, R. B. (1989). Indirect tactics of image management: Beyond basking. In R. A. Giacalone \& P. Rosenfeld (Eds.), Impression management in the organization (pp. 45-56). Hillsdale, NJ: Erlbaum.

Cialdini, R. B., Schaller, M., Houlihan, D., Arps, K., Fultz, J., \& Beaman, A. L. (1987). Empathy-based helping: Is it selflessly or selfishly motivated? Journal of Personality and Social Psychology, 52, 749-758.

Coffman, S. E. (2000). Women and philanthropy. Retrieved April 17, 2007, from http://www.guidestar.org/news/features/women.jsp

Cole, D., \& Chaikin, I. (1990). An iron band upon the people. Seattle, WA: University of Washington Press.

Cosmides, L., \& Tooby, J. (1992). Cognitive adaptations for social exchange. In J. H. Barkow, L. Cosmides, and J. Tooby, (Eds.), The adapted mind (pp. 163-228). Oxford, United Kingdom: Oxford University Press.

Daly, M., \& Wilson, M. (1988). Homicide. Hawthorne, NY: Aldine de Gruyter.

Dawkins, R. (1989). The selfish gene (2nd ed.). New York: Oxford University Press.

Dugatkin, L. A. (1997). Cooperation among animals: An evolutionary perspective. Oxford, United Kingdom: Oxford University Press.

Ellis, B. J. (1992). The evolution of sexual attraction: Evaluative mechanisms in women. In J. H. Barkow, L. Cosmides, \& J. Tooby (Eds.), The adapted mind and the generation of culture (pp. 267-288). New York: Oxford University Press.

Essock-Vitale, S. M., \& McGuire, M. T. (1985). Women's lives viewed from an evolutionary perspective: II. Patterns of helping. Ethology and Sociobiology, 6, 155-173.
Farthing, G. W. (2005). Attitudes toward heroic and nonheroic physical risk takers as mates and as friends. Evolution and Human Behavior, 26, 171-185.

Fehr, E., Gachter, S., \& Kirchsteiger, G. (1997). Reciprocity as a contract enforcement device. Econometrica, 65, 833-860.

Feingold, A. (1992). Gender differences in mate selection preferences: A test of the parental investment model. Psychological Bulletin, 112, $125-139$.

Fishbein, M., \& Ajzen, I. (1975). Belief, attitude, intention, and behavior: An introduction to theory and research. Reading, MA: AddisonWesley.

Fisher, H. (2002). Defining the brain systems of lust, romantic attraction, and attachment. Archives of Sexual Behavior, 31, 413-419.

Foundation Center. (2003, September 14). Trump steps up philanthropy in New York City. Retrieved May 4, 2007, from http://foundationcenter .org/newyork/gitn/ny_gitn_021403.html

Frank, R. H. (1999). Luxury fever: Money and happiness in an era of excess. Princeton, NJ: Princeton University Press.

Gangestad, S. W., \& Simpson, J. A. (2000). On the evolutionary psychology of human mating: Trade-offs and strategic pluralism. Behavioral and Brain Sciences, 23, 573-587.

Gangestad, S. W., Simpson, J. A., Cousins, A. J., Garver-Apgar, C. E., \& Christensen, P. N. (2004). Women's preferences for male behavioral displays change across the menstrual cycle. Psychological Science, 15, 203-207.

Goldberg, T. L. (1995). Altruism towards panhandlers: Who gives? Human Nature, 6, 79-90.

Grafen, A. (1990). Biological signals as handicaps. Journal of Theoretical Biology, 144, 517-546.

Graziano, W. G., Jensen-Campbell, L. A., Todd, M., \& Finch, J. F. (1997). Interpersonal attraction from an evolutionary perspective: Women's reactions to dominant and prosocial men. In J. A. Simpson \& D. T. Kenrick (Eds.), Evolutionary social psychology (pp. 141-167). Mahwah, NJ: Erlbaum.

Green, B. L., \& Kenrick, D. T. (1994). The attractiveness of gender-typed traits at different relationship levels: Androgynous characteristics may be desirable after all. Personality and Social Psychology Bulletin, 20, $244-253$.

Griskevicius, V., Cialdini, R. B., \& Kenrick, D. T. (2006). Peacocks, Picasso, and parental investment: The effects of romantic motives on creativity. Journal of Personality and Social Psychology, 91, 52-66.

Griskevicius, V., Goldstein, N. J., Mortensen, C. R., Cialdini, R. B., \& Kenrick, D. T. (2006). Going along versus going alone: When fundamental motives facilitate strategic (non)conformity. Journal of Personality and Social Psychology, 91, 281-294.

Griskevicius, V., Goldstein, N. J., Mortensen, C. R., Sundie, J. M., Cialdini, R. B., \& Kenrick, D. T. (2006). Fear and loving in Las Vegas: When fundamental motives cause basic persuasion principle to backfire. Manuscript submitted for publication.

Gurven, M., Allen-Arave, W., Hill, K., \& Hurtado, M. (2000). It's a wonderful life: Signaling generosity among the Ache of Paraguay. Evolution and Human Behavior, 21, 263-282.

Hamilton, W. D. (1964). The genetical evolution of social behavior: I and II. Journal of Theoretical Biology, 7, 1-52.

Hardy, C. L., \& Van Vugt, M. (2006). Nice guys finish first: The competitive altruism hypothesis. Personality and Social Psychology Bulletin, 32, 1402-1413.

Hawkes, K. (1992). Sharing and collective action. In E. A. Smith and B. Winterhalder (Eds.), Ecology, evolution, and human behavior (pp. 269300). New York: Aldine de Gruyter.

Hawkes, K., \& Bird, R. (2002). Showing off, handicap signaling, and the evolution of men's work. Evolutionary Anthropology, 11, 58-67.

Higgins, E. T. (1996). Knowledge activation: Accessibility, applicability, and salience. In E. T. Higgins and A. W. Kruglanski (Eds.), Social 
psychology: Handbook of basic principles (pp. 133-168). New York: Guilford.

Jensen-Campbell, L. A., Graziano, W., \& West, S. G. (1995). Dominance, prosocial orientation, and female preferences: Do nice guys really finish last? Journal of Personality and Social Psychology, 68, 427-440.

Johnson, R. C. (1996). Attributes of Carnegie medalists performing acts of heroism and the recipients of these acts. Ethology and Sociobiology, 17, 355-362.

Kelly, S., \& Dunbar, R. (2001). Who dares wins: Heroism versus altruism in women's mate choice. Human Nature, 12, 89-105.

Kenrick, D. T., Li, N. P., \& Butner, J. (2003). Dynamical evolutionary psychology: Individual decision rules and emergent social norms. Psychological Review, 110, 3-28.

Kenrick, D. T., Sadalla, E. K., Groth, G., \& Trost, M. R. (1990). Evolution, traits, and the stages of human courtship: Qualifying the parental investment model. Journal of Personality, 58, 97-117.

Kenrick, D. T., Sundie, J. M., Nicastle, L. D., \& Stone, G. O. (2001). Can one ever be too wealthy or too chaste? Searching for nonlinearities in mate judgment. Journal of Personality and Social Psychology, 80, 462-471.

Kenrick, D. T., Trost, M. R., \& Sundie, J. M. (2004). Sex-roles as adaptations: An evolutionary perspective on gender differences and similarities. In A. H. Eagly, A. Beall, \& R. Sternberg (Eds.), Psychology of gender (pp. 65-91). New York: Guilford.

La Cerra, M. M. (1995). Evolved mate preferences in women: Psychological adaptations for assessing a man's willingness to invest in offspring. Unpublished doctoral dissertation, University of California, Santa Barbara.

Latane, B., \& Darley, J. M. (1970). The unresponsive bystander: Why doesn't he help? New York: Appleton-Century-Croft.

Li, N. P., Bailey, J. M., Kenrick, D. T., \& Linsenmeier, J. A. (2002). The necessities and luxuries of mate preferences: Testing the trade-offs. Journal of Personality and Social Psychology, 82, 947-955.

Li, N. P., \& Kenrick, D. T. (2006). Sex similarities and differences in preferences for short-term mates: What, whether, and why. Journal of Personality and Social Psychology, 90, 468-489.

Lotem, A., Fishman, M. A., \& Stone, L. (2002). From reciprocity to unconditional altruism through signaling benefits. Proceedings of the Royal Society of London, Series B: Biological Sciences, 270, 199-205.

Loyau, A., Saint Jalme, M., Cagniant, C., \& Sorci, G. (2005). Multiple sexual advertisements honestly reflect health status in peacocks (Pavo cristatus). Behavioral Ecology and Sociobiology, 58, 552-557.

MacAndrew, F. T. (2002). New evolutionary perspective on altruism: Multilevel-selection and costly-signaling theories. Current Directions in Psychological Science, 11, 79-82.

Maner, J. K., Kenrick, D. T., Becker, D. V., Robertson, T. E., Hofer, B., Neuberg, S. N., et al. (2005). Functional projection: How fundamental social motives can bias interpersonal perception. Journal of Personality and Social Psychology, 88, 63-78.

Mauss, M. (1924). The gift: Forms and functions of exchange in archaic societies. London: Cohen and West.

Miller, G. F. (2000). The mating mind: How sexual choice shaped the evolution of human nature. New York: Doubleday.

Miller, G. F. (2007). Sexual selection for moral virtues. Quarterly Review of Biology, 82, 97-125.

Miller, G. F., \& Todd, P. M. (1998). Mate choice turns cognitive. Trends in Cognitive Sciences, 2, 190-198.

Møller, A. P., \& Petrie, M. (2002). Condition dependence, multiple sexual signals, and immunocompetence in peacocks. Behavioral Ecology, 13, $248-253$.

Murdock, G. P. (1970). Rank and potlatch among the Haida (Yale University Publications in Anthropology Series, No. 13). New Haven, CT: Human Relations Area Files Press. (Original work published 1936)

Neyer, F. J., \& Lang, F. R. (2003). Blood is thicker than water: Kinship orientation across adulthood. Journal of Personality and Social Psychology, 84, 310-321.

Öhman, A., \& Mineka, S. (2001). Fears, phobias, and preparedness: Toward an evolved module of fear and fear learning. Psychology Review, 108, 483-522.

Penner, L. A., Dovidio, J. F., Piliavin, J. A., \& Schroeder, D. A. (2005). Prosocial behavior: Multilevel perspectives. Annual Review of Psychology, 56, 365-392.

Penner, L. A., \& Finkelstein, M. A. (1998). Dispositional and structural determinants of volunteerism. Journal of Personality and Social Psychology, 74, 525-537.

Petty, R. E., \& Cacioppo, J. T. (1981). Attitudes and persuasion: Classic and contemporary approaches. Dubuque, IA: Brown.

Piliavin, J. A., \& Callero, P. L. (1991). Giving blood: The development of an altruistic identity. Baltimore: Johns Hopkins Press.

Plotz, M. (2006). Competitive philanthropy: The history of the Slate 60. Retrieved April 17, 2007, from http://www.slate.com/id/2136385/

Plutchik, R. (1980). A general psychoevolutionary theory of emotion. In R. Plutchik \& H. Kellerman (Eds.), Emotion: Theory, research, and experience: Vol. 1. Theories of emotion (pp. 3-33). New York: Academic Press.

Roberts, G. (1998). Competitive altruism: From reciprocity to the handicap principle. Proceedings of the Royal Society of London, Series B: Biological Sciences, 265, 427-431.

Roney, J. R. (2003). Effects of visual exposure to the opposite sex: Cognitive aspects of mate attraction in human males. Personality and Social Psychology Bulletin, 29, 393-404.

Rosman, A., \& Rubel, P. G. (1971). Feasting with mine enemy. New York: Columbia University Press.

Saad, G. (2007). The evolutionary bases of consumption. Mahwah, NJ: Erlbaum.

Saad, G., \& Gill, T. (2003). An evolutionary psychology perspective on gift-giving among young adults. Psychology \& Marketing, 20, 765-784.

Sadalla, E. K., Kenrick, D. T., \& Vershure, B. (1987). Dominance and heterosexual attraction. Journal of Personality and Social Psychology, $52,730-738$.

Schaller, M. (2003). Ancestral environments and motivated social perception: Goal-like blasts from the evolutionary past. In S. J. Spencer, S. Fein., M. P. Zanna, \& J. M. Olson (Eds.), Motivated social perception (pp. 215-231). Mahwah NJ: Erlbaum.

Schaller, M., \& Cialdini, R. B., (1990). Happiness, sadness, and helping: A motivational integration. In E. T. Higgins \& R. M. Sorrentino (Eds.), Handbook of motivation and cognition (Vol. 2, pp. 265-296). New York: Guilford.

Schaller, M., Park, J. H., \& Kenrick, D. T. (2007). Human evolution and social cognition. In R. I. M. Dunbar \& L. Barrett (Eds.), The Oxford handbook of evolutionary psychology (pp. 491-504). Oxford, United Kingdom: Oxford University Press.

Schaller, M., Park, J. H., \& Mueller, A. (2003). Fear of the dark: Interactive effects of beliefs about danger and ambient darkness on ethnic stereotypes. Personality and Social Psychology Bulletin, 29, 637-649.

Sherman, P. W. (1981). Kinship, demography, and Belding's ground squirrel nepotism. Behavioral Ecology and Sociology, 8, 604-606.

Silverstein, M., \& Fiske, N. (2003). Trading up: The new American luxury. New York: Portfolio.

Simpson, J. A., \& Gangestad, S. W. (1991). Individual differences in sociosexuality: Evidence for converging and discriminant validity. Journal of Personality and Social Psychology, 67, 870-883.

Simpson, J. A., \& Gangestad, S. W. (1992). Sociosexuality and romantic partner choice. Journal of Personality, 60, 31-51.

Simpson, J. A., Gangestad, S. W., Christensen, P. N., \& Leck, K. (1999). Fluctuating asymmetry, sociosexuality, and intrasexual competitive tactics. Journal of Personality and Social Psychology, 76, 159-172.

Smith, E. A., \& Bird, R. L. (2000). Turtle hunting and tombstone opening: 
Public generosity as costly signaling. Evolution and Human Behavior, 21, 245-261.

Snyder, C. R., Lassegard, M., \& Ford, C. E. (1986). Distancing after group success and failure: Basking in reflected glory and cutting off reflected failure. Journal of Personality and Social Psychology, 51, 383-388.

Sosis, R. (2000). Costly signaling and torch fishing on Ifaluk Atoll. Evolution and Human Behavior, 21, 223-244.

Srull, T. K., \& Wyer, R. S. (1979). The role of category accessibility in the interpretation of information about persons: Some determinant and implications. Journal of Personality and Social Psychology, 37, 16601672.

Stanne, M. B., Johnson, D. W., \& Johnson, R. T. (1999). Does competition enhance or inhibit motor performance: A meta-analysis. Psychological Bulletin, 125, 133-154.

Sundie, J. M., Kenrick, D. T., Griskevicius, V., \& Tybur, J. M. (2007). Peacocks, Porsches, and Thorstein Veblen: Conspicuous consumption as sexual signaling. Manuscript under review.

Suttles, W. (1991). Streams of property, armor of wealth: The traditional Kwakiutl potlatch. In A. Jonaitis (Ed.), Chiefly feasts: The enduring Kwakiutl potlatch (pp. 71-133). Seattle: University of Washington Press.

Taylor, S. E., Klein, L. C., Lewis, B. P., Gruenwald, T. L., Gurung, R. A. R., \& Updegraff, J. A. (2000). Biobehavioral responses to stress in females: Tend-and-befriend, not fight-or-flight. Psychological Review, 107, 411-429.

Townsend, J. M., \& Levy, G. D. (1990). Effects of potential partners' physical attractiveness and socioeconomic status on sexuality and partner selection. Archives of Sexual Behavior, 19, 149-164.
Trivers, R. L. (1971). The evolution of reciprocal altruism. Quarterly Review of Biology, 46, 35-57.

Twitchel, J. B. (2003). Living it up: Our love affair with luxury. New York: Columbia University Press.

Van Lange, P. A. M., Otten, W., DeBruin, E. M. N., \& Joireman, J. A. (1997). Development of prosocial, individualistic, and competitive orientations: Theory and preliminary evidence. Journal of Personality and Social Psychology, 73, 733-746.

Van Vugt, M., \& Van Lange, P. A. M. (2006). Psychological adaptations for prosocial behavior: The altruism puzzle. In M. Schaller, J. Simpson, \& D. Kenrick (Eds.), Evolution and Social Psychology (pp. 237-262). New York: Psychology Press.

Veblen, T. (1994). The theory of the leisure class. New York: Dover. (Original work published 1899)

Wilkinson, G. W. (1984, March 8). Reciprocal food sharing in the vampire bat. Nature, 308, 181-184.

Wilson, M., \& Daly, M. (2004). Do pretty women inspire men to discount the future? Proceedings of the Royal Society of London, Series B: Biological Sciences, 271(Suppl. 4), 177-179.

Zahavi, A. (1975). Mate selection: Selection for a handicap. Journal of Theoretical Biology, 53, 205-214.

Zahavi, A., \& Zahavi, A. (1997). The handicap principle: A missing piece of Darwin's puzzle. New York: Oxford University Press.

Received June 6, 2006

Revision received October 24, 2006

Accepted October 26, 2006 